\title{
New species of thorny catfish, genus Leptodoras Boulenger (Siluriformes: Doradidae), from Tapajós and Xingu basins, Brazil
}

\author{
José L. O. Birindelli ${ }^{1}$, Leandro M. Sousa ${ }^{1}$ and Mark H. Sabaj Pérez ${ }^{2}$
}

\begin{abstract}
A new species of thorny catfish (family Doradidae) is described as a member of genus Leptodoras Boulenger by having a modified oral hood and first gill arch with enlarged accessory lamellae extending well onto medial face of gill filaments. The new species is distinguished by three characteristics unique within Leptodoras: gas bladder moderately sized (not reduced) with simple walls (diverticula absent), and paired bony capsules on anteriormost vertebrae reduced to paired cup-like laminar ossifications separated by triangular septum. The new species was discovered from material recently collected in the Tapajós basin at Serra do Cachimbo and in the headwaters of rio Xingu. The species description is supplemented by a detailed osteological description, discussion on its placement among congeners, and a re-evaluation of the diagnosis of Leptodoras and its relationships with sister taxon Anduzedoras oxyrhynchus. In addition, the distributions of several species of Leptodoras are expanded based on recent collecting efforts and identification of museum specimens not previously studied.

Uma nova espécie de botoado da família Doradidae é descrita. A nova espécie é incluída no gênero Leptodoras Boulenger por possuir capuz oral modificado e primeiro arco branquial com lamelas acessórias bem desenvolvidas estendidas sobre a face medial dos filamentos branquiais. A nova espécie distingue-se dentre Leptodoras por três características únicas: bexiga natatória de tamanho moderado (não reduzida), com paredes simples (sem divertículos), e cápsulas ósseas pares sobre as vértebras anteriores reduzidas a um par de ossificações laminares em formato de cuia separadas por septo triangular. A nova espécie foi descoberta a partir do material coletado na bacia do rio Tapajós na Serra do Cachimbo e nas cabeceiras do rio Xingu. A descrição da espécie é suplementada por uma descrição osteológica detalhada, discussão sobre o seu posicionamento dentre os congêneres, re-avaliação da diagnose de Leptodoras e sua relação com o táxon irmão Anduzedoras oxyrhynchus. Além disso, a distribuição de diversas espécies de Leptodoras é revisada com base nos recentes esforços de coleta e na identificação de espécimes de museus não previamente estudados.
\end{abstract}

Key words: Leptodoras oyakawai, Central Brazil, Rio Jamanxim, Rio Teles Pires, Rio Culuene.

\section{Introduction}

The family Doradidae is a monophyletic group promptly diagnosed by a single characteristic unique among Siluriformes: the presence of an infranuchal scute. The infranuchal scute is a bony laminar expansion of a ligament between the posterior nuchal plate and first rib, borne on the six vertebra, that is associated with the lateral line canal and usually contacts, underlies or approaches the medial face of postcleithral process ventrally. The infranuchal scute is the first in a series of well-developed midlateral scutes that are characteristic of most doradids. The midlateral scutes, sepa- rate ossifications of the lateral-line canal, usually have dorsal and ventral laminar expansions (wings) that flank a central thorn or longitudinal carina.

The family Doradidae comprises about 85 valid extant species plus one fossil species arranged in 31 genera (Ferraris, 2007; Birindelli et al., 2007; Higuchi et al., 2007; Sabaj Pérez et al., 2007; Sabaj et al., 2008; Sabaj Pérez \& Birindelli, 2008). Leptodoras Boulenger is the largest doradid genus with 10 valid species, three of which were recently described by Sabaj (2005). The genus is among the most derived within the monophyletic clade of fimbriate-barbel doradids (Higuchi, 1992; Moyer et al., 2004; Birindelli, 2006), and is easily recognized

\footnotetext{
${ }^{1}$ Museu de Zoologia da Universidade de São Paulo, Caixa Postal 42494, 04218-970 São Paulo, SP, Brazil. josebirindelli@yahoo.com; leandro.m.sousa@gmail.com ${ }^{2}$ Department of Ichthyology, The Academy of Natural Sciences, 1900 Benjamin Franklin Parkway, Philadelphia, PA, USA 19103. sabaj@acnatsci.org
} 
by the long conical snout and well-developed oral hood formed by the membranous union of maxillary barbels, jaw barbels and labial expansions (Sabaj, 2005). Species of Leptodoras are mainly benthic and inhabit the main channels of moderate to large rivers, in slow to swift currents often over sandy substrates.

A new species of Leptodoras was recently discovered in the Tapajós basin at Serra do Cachimbo and the upper Xingu basin, in the states of Pará and Mato Grosso, Brazil. Recent collecting efforts in this region and identifications of museum specimens not studied by Sabaj (2005) have significantly increased the known ranges of many species of Leptodoras. The objectives of this paper are to describe a new species of Leptodoras including details on its osteology, discuss its placement within Leptodoras, re-evaluate the diagnosis of the genus, and discuss its relationship with sister taxon Anduzedoras oxyrhynchus.

\section{Material and Methods}

Methodology and terminology for measurements follow Sabaj (2005). Standard length (SL) is expressed in $\mathrm{mm}$ and other measurements are expressed as either percentage of standard length or, for subunits of head, predorsal distance. Measurements and counts were taken on left side of specimens whenever possible. Meristic data are given in the description, followed by the number of specimens for each count in parentheses. Meristic data of the holotype are indicated in the text by an asterisk. Counts of branchiostegal rays and vertebrae were determined in dry skeletons (sk) and cleared and stained (cs) material prepared according to procedures of Taylor \& Van Dyke (1985); all other examined specimens were alcohol preserved. Osteological terminology generally follows Arratia (2003a, b) and Chardon et al. (2003). Institutional abbreviations follow Ferraris (2007).

\section{Results}

\section{Leptodoras oyakawai, new species}

Figs. 1 and 2

Holotype. MZUSP 97909 (120.5 mm SL), Brazil, Pará, Novo Progresso, rio Jamanxim (Tapajós basin), at Prainha, near Novo Progresso, 0703'51'S 55²6’28”'W, 24 Oct 2007, J. L. O. Birindelli, L. M. Sousa, M. H. Sabaj Pérez, A. Netto Ferreira, N. Lujan.

Paratypes. ANSP 187336 (1, $123.5 \mathrm{~mm} \mathrm{SL}, 1 \mathrm{sk}, 120 \mathrm{~mm} \mathrm{SL})$; MZUSP 97395 (2, 82.2-121.9 mm SL); collected with holotype. Non-types. All from Brazil, Mato Grosso. Tapajós basin: ANSP 187415 (2, 63.0-72.2 mm SL), AUM 47567 (2, 66.6-72.0 mm SL), MZUSP 95722 (5, 51.8-89.8 mm SL, 1 cs, 73.0 mm SL), Paranaíta, rio Teles Pires, near ferry boat of road MT-416, 09²7'07'S $56^{\circ} 30^{\prime} 46^{\prime \prime} W, 27$ Sep 2007, L. M. Sousa, A. Netto Ferreira. INPA 28856 (2, 59.9-70.1 mm SL), MCP 42796 (1, $58.1 \mathrm{~mm} \mathrm{SL})$, MZUSP 96597 (7, 52.4-71.6 mm SL), Peixoto de Azevedo, rio Peixoto de Azevedo, tributary of rio Teles Pires, $10^{\circ} 13^{\prime} 14^{\prime \prime} \mathrm{S} 54^{\circ} 58^{\prime} 02^{\prime \prime} \mathrm{W}, 16$ Oct 2007, J. L. O. Birindelli, L. M. Sousa, M. H. Sabaj Pérez, A. Netto Ferreira, N. Lujan. Xingu basin: ANSP 187417 (3, 86.4-96.6 mm SL), MZUSP 91979 (15, 75.6-108.7 mm SL), Campinápolis, rio Culuene, in former area of PCH Paranatinga II, $13^{\circ} 49^{\prime} \mathrm{S} 53^{\circ} 15^{\prime} \mathrm{W}$, 24 Oct 2007, J. L. O. Birindelli, L. M. Sousa, A. Akama. MNRJ 31915 (3, 79.9-85.1 mm SL), MZUSP 94141 (22, 63.0-96.3 mm SL, 1 cs, $96.0 \mathrm{~mm} \mathrm{SL})$, Gaúcha do Norte, rio Culuene, Fazenda do

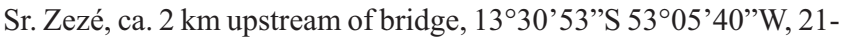
26 May 2007, J. L. O. Birindelli, F. C. T. Lima, C. A. Figueiredo, F. A. Machado. MZUSP 86992 (1, $62.8 \mathrm{~mm} \mathrm{SL})$, Gaúcha do Norte, rio Culuene, $13^{\circ} 30$ '52"S $53^{\circ} 05^{\prime} 34^{\prime} \mathrm{W}, 19$ Oct 2004, J. L. O. Birindelli, O. T. Oyakawa, J. C. Nolasco. MZUSP 87028 (13, 55.9$94.8 \mathrm{~mm} \mathrm{SL})$, Gaúcha do Norte, rio Curisevo, Porto Vitório, near ribeirão Kevuaieli, $13^{\circ} 02^{\prime} 05^{\prime \prime S} 53^{\circ} 23^{\prime} 19^{\prime \prime} \mathrm{W}, 19$ Oct 2004, C. R. Moreira, M. I. Landim, A. K. Oliveira, A. Datovo. MZUSP 98216 (3, 69.9-103.5 mm SL), Campinápolis, rio Culuene, below $\mathrm{PCH}$ Paranatinga $2,13^{\circ} 50^{\prime} 00^{\prime} \mathrm{S} 53^{\circ} 15^{\prime} 00^{\prime} \mathrm{W}, 02$ Oct 2007 , F. C. T. Lima, F. Machado, C. R. Moreira, A. Ribeiro.

Diagnosis. Leptodoras oyakawai is a member of the genus Leptodoras by having a modified oral hood (see Fig. 3) and the first gill arch with enlarged accessory lamellae extending well onto the medial (postaxial) face of the gill filaments (see Fig. 4). Leptodoras oyakawai is distinguished by three characteristics unique within Leptodoras: gas bladder moderately sized (not reduced) and with simple walls (diverticula absent; see Fig. 5), and paired bony capsules on anteriormost vertebrae reduced to paired cup-like laminar ossifications separated by a triangular septum (see Fig. 6).

Comparisons. All other species of Leptodoras have a reduced gas bladder with two large, horn-like diverticula, one extending from each posterior chamber, and a pair of smaller diverticula on each lateral wall of anterior chamber. All other species of Leptodoras also have superficial ossifications covering the anteriormost vertebrae expanded ventrally into a conjoined pair of bony capsules that are intimately associated with the anterior wall of gas bladder (see Fig. 6).

Leptodoras oyakawai is further distinguished from all species of Leptodoras except $L$. copei and L. praelongus by having basal third to half of dorsal-fin spine blackened (dark pigment also usually present along base of dorsal fin forming a triangular blotch tapered posteriorly) and lower labial extension of modified oral hood extending more posteriorly than upper labial extension (see Fig. 3). Leptodoras oyakawai has relatively few midlateral scutes (33-37 per side) similar to $L$. copei (35-37) and L. praelongus (35-38) vs. 37-46 scutes in all other species of Leptodoras.

In L. oyakawai, as in most species of Leptodoras, the anterior nuchal plate is well-developed and laterally expanded, and the parieto-supraoccipital does not contact the middle nuchal plate (Figs. 7a-b) vs. anterior nuchal plate reduced, permitting contact between parieto-supraoccipital and middle nuchal plate in most specimens of $L$. praelongus.

Description. Examined material 51.8 to $123.5 \mathrm{~mm} \mathrm{SL}(\mathrm{n}=86)$. Measurements of holotype, paratypes and non-type specimens in Table 1. Dorsal, lateral and ventral views of holotype in Fig. 1. Body elongate, slightly compressed, deepest at dor- 


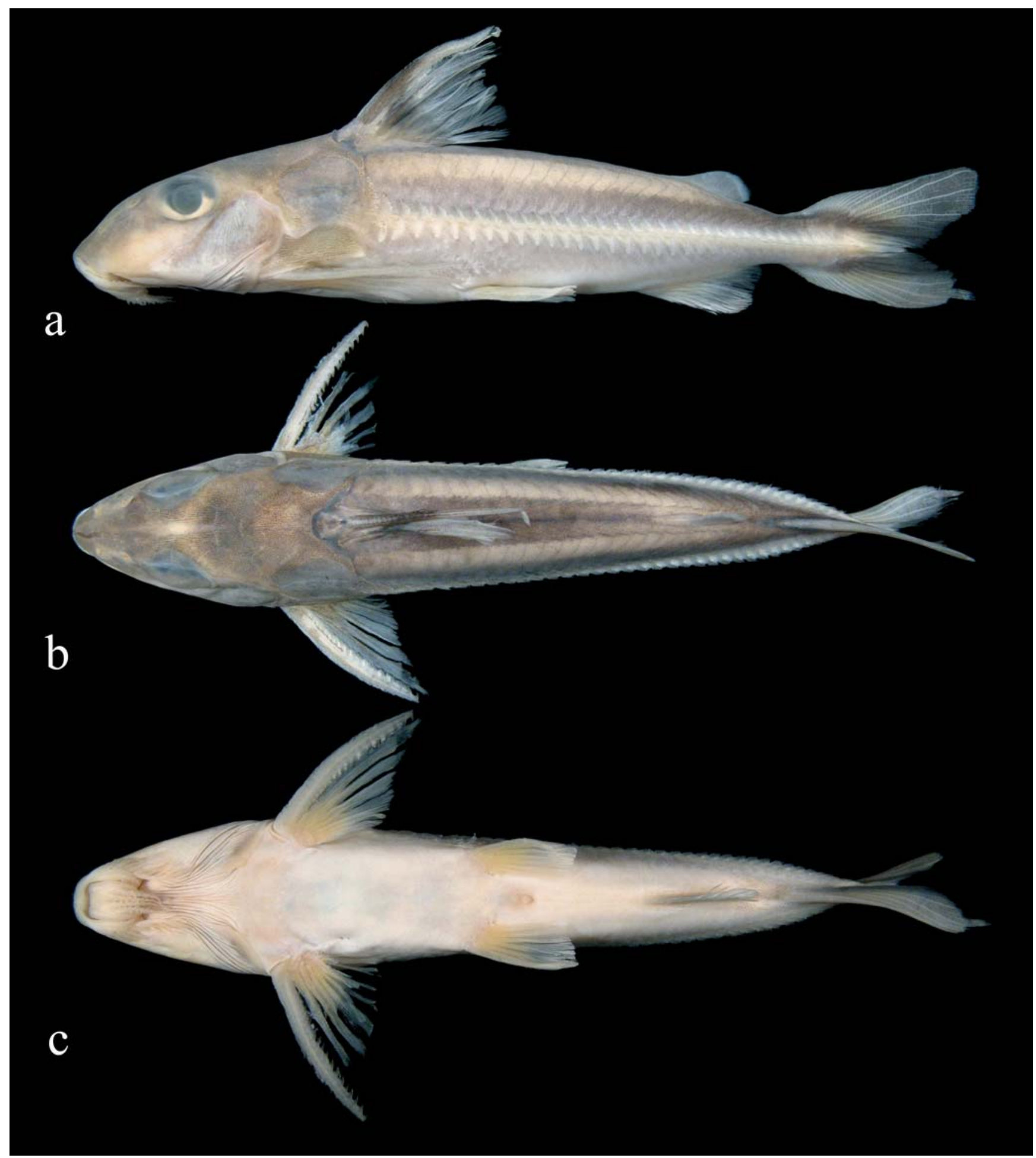

Fig. 1. Leptodoras oyakawai, MZUSP 97909, holotype, 120.5 mm SL, in (a) lateral, (b) dorsal and (c) ventral views. Brazil, Pará, Novo Progresso, rio Jamanxim (Tapajós basin), at Prainha, near Novo Progresso.

sal-fin origin, gently tapering to short, slender caudal peduncle. Ventral surface flattened from mouth to anal-fin origin. Head large, deep, weakly compressed with conical snout; dorsal profile straight to weakly convex from snout tip to between anterior and posterior nares, then curving gently (convex) to interorbital region and finishing straight, weakly oblique to dorsal-fin origin. Eye large, dorsolateral, covered by thick layer of adipose tissue; dorsal margin of orbit strongly concave and medially turned; interorbital moderately narrow, $7.0-13.9 \%$ of predorsal length.

Mouth subterminal; jaws edentulous in adults and juveniles as small as $51.8 \mathrm{~mm} \mathrm{SL}$; gape rounded anteriorly and 


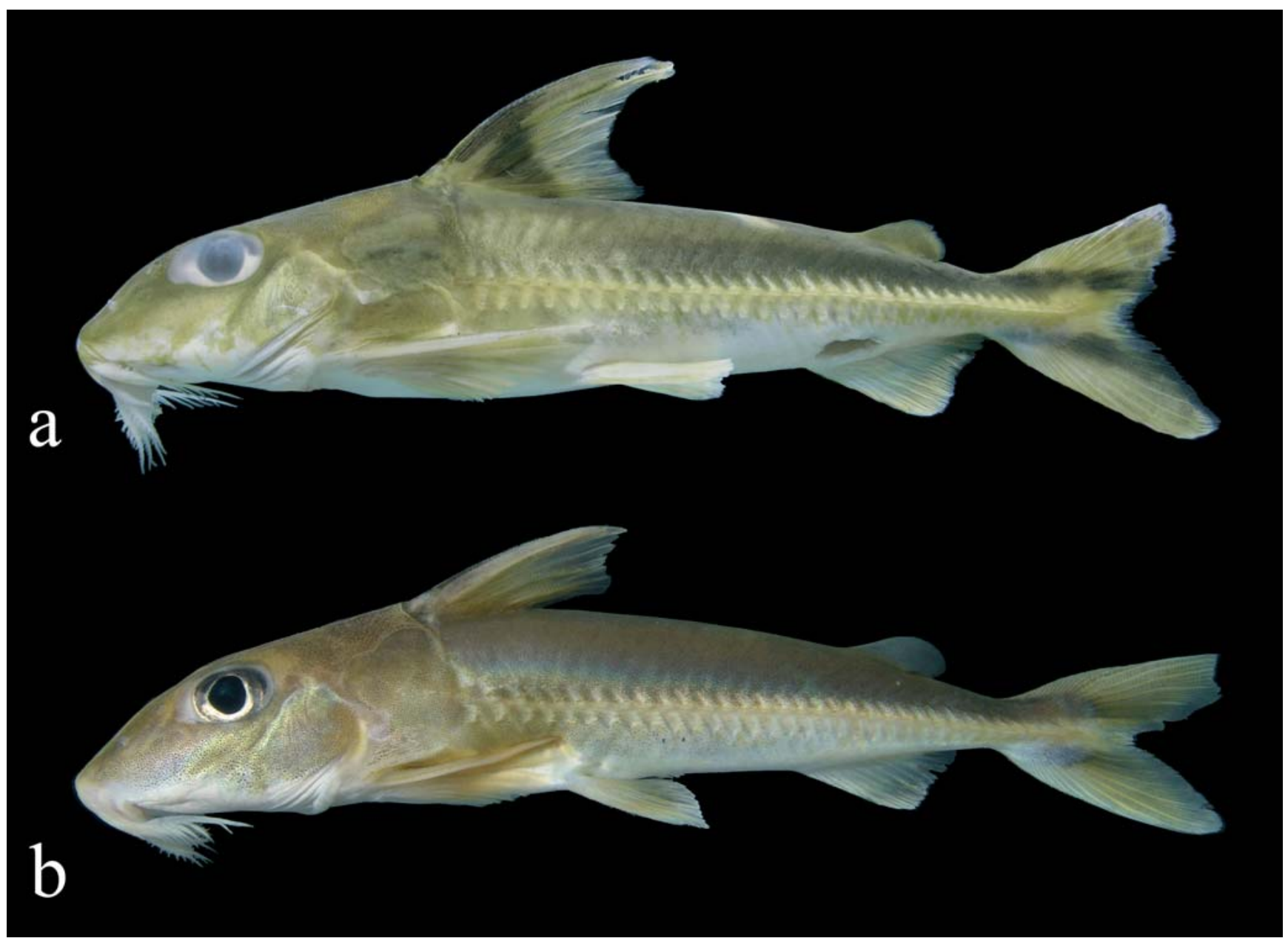

Fig. 2. Leptodoras oyakawai in lateral view: (a) MZUSP 97395, paratype, $222.4 \mathrm{~mm}$ SL, rio Jamanxim, Tapajós basin, photographed immediately after preservation (right side of body), (b) MZUSP 91979, 108.7 mm SL, rio Culuene, upper Xingu basin, photographed live (left side of body).

straight with slight elevation at symphysis posteriorly.

Three pairs of barbels: maxillary, inner and outer mental (Fig. 3). Maxillary barbel relatively short, tip finishing shy of medialmost terminus of gill opening in adults, extending to or slightly beyond in juveniles; fimbriate with about nine secondary barbels along lateral margin; proximal ones overlapping and rugose with papillae along dorsal surface; distal ones more spaced and simple. Upper labial extension lanceolate (tapered distally), moderately elongate, relatively thick, straight to weakly curved medially, with ventral surface largely smooth or sometimes with small papillae distally. Lower labial extension narrower, attenuate, relatively straight (tip may be curled dorsally due to preservation), with ventral surface largely smooth or sometimes with small papillae/fimbriae distally. Lower labial extension finishes slightly to distinctly more posteriorly than upper labial extension. Interlabial membrane thin with slightly thicker longitudinal striations; ventral surface with small papillae in distal half; distal margin moderately wide (i.e., upper and lower labial extensions separated). Mental barbels profusely ornamented with fleshy papillae;

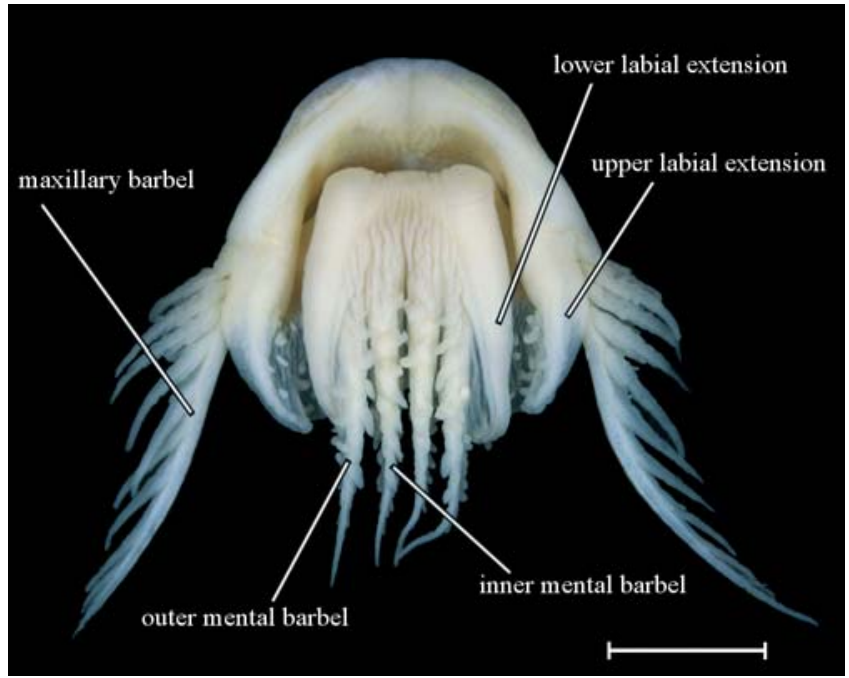

Fig. 3. Mouth, barbels and lips of Leptodoras oyakawai, MZUSP 97909, holotype, $120.5 \mathrm{~mm}$ SL, in ventral view. Scale bar $5 \mathrm{~mm}$. 


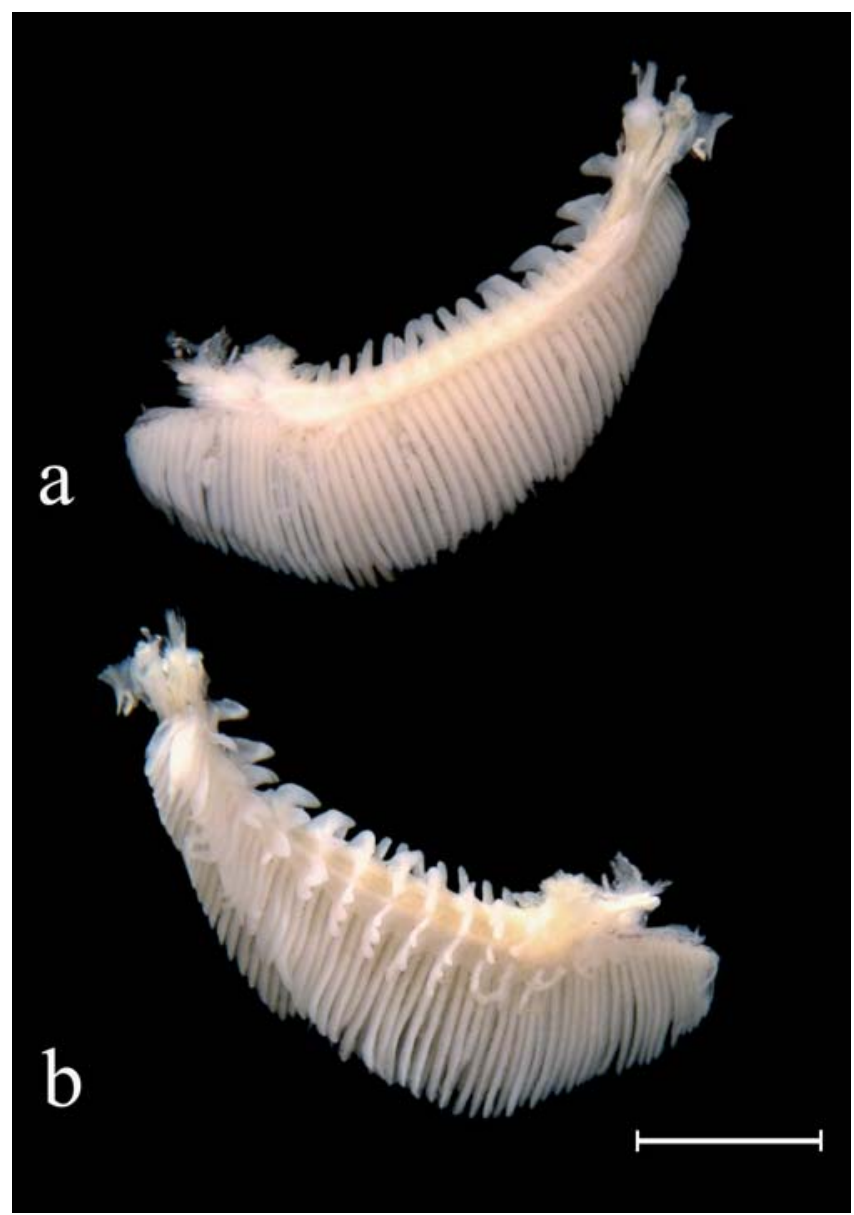

Fig. 4. First gill arch of Leptodoras oyakawai, MZUSP 97395 , paratype, showing accessory lamellae, in (a) lateral and (b) medial views. Scale bar $5 \mathrm{~mm}$.

outer pair finishing slightly posterior to inner pair. Basal portions of mental barbels united by thin membrane with thicker longitudinal striations and small fimbriae along distal margin. Dorsolabial membrane absent.

Anterior and posterior nares separated, openings surrounded by tube of skin; posterior wall of tube surrounding anterior naris slightly expanded as small flap; anterior wall of posterior naris also expanded as small flap. Anterior naris located between snout tip and posterior naris; posterior naris larger than anterior, much closer to anterior margin of orbit than to anterior naris.

First ceratobranchial with 16-21 short rakers (2-3 upper, 14-18 lower; $\mathrm{n}=3$, SL 73-122.5 mm); entire raker (i.e., ossified acicular portion and skin covering) narrowly subtriangular with transversely oriented base. Medial face of first ceratobranchial with thin, soft, and fleshy triangular lamellae (Fig. 4). Lamellae arranged into distinctly spaced columns more or less perpendicular to axis of lower arch and loosely aligned with every second raker and every third gill filament. Lamellar columns extending from base of rakers onto basal third to half of filaments. Innermost lamella (nearest rakers)

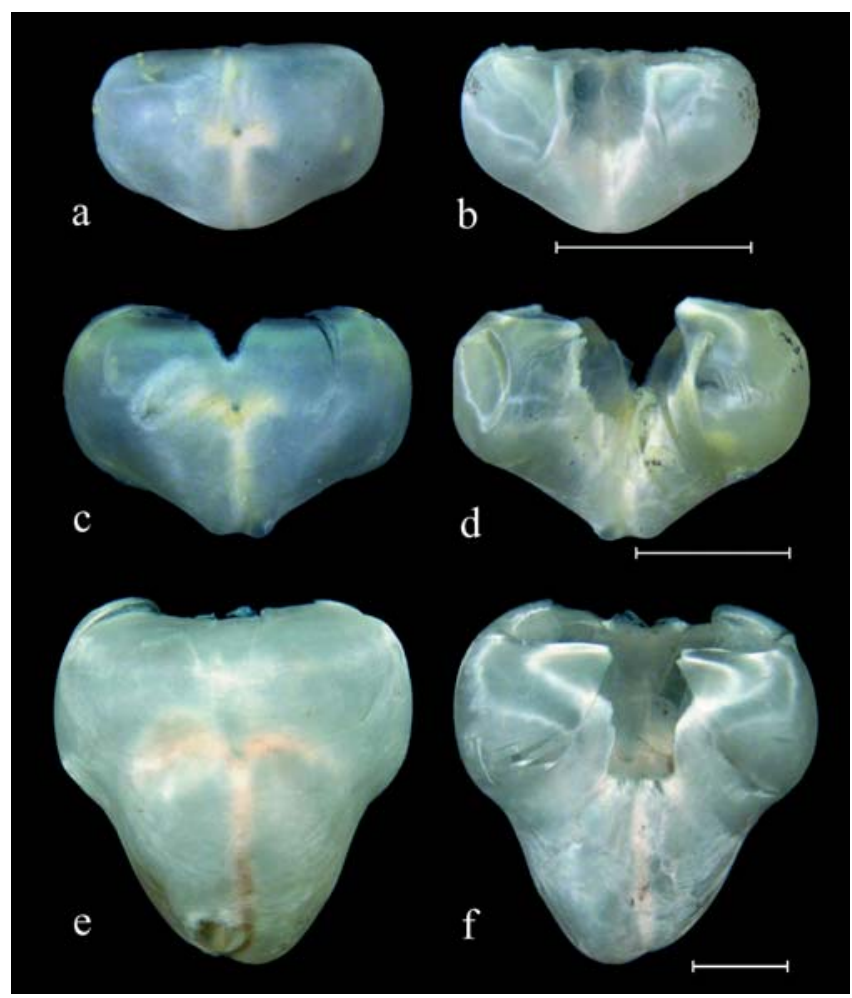

Fig. 5. Gas bladder of Leptodoras oyakawai, MZUSP 87028, $54 \mathrm{~mm}$ SL in (a) ventral and (b) dorsal views; MZUSP 95722, $88 \mathrm{~mm}$ SL in (c) ventral and (d) dorsal views; MZUSP 97395, $121.9 \mathrm{~mm}$ SL in (e) ventral and (f) dorsal views. Scale bar $5 \mathrm{~mm}$.

largest in each column; lamellae becoming gradually smaller outwardly. Outermost lamellae in each column conjoined and weakly adhered to gill filament (attachment easily broken, may be lost in adults). Bases of filaments skirted by thin membrane from which outermost lamellae originate. Branchiostegal membrane broadly united to isthmus; distal free portion narrowly expanded with fleshy margin.

Skin relatively smooth except for extremely minute punctate to dash-like tubercles most abundant on snout. Skin between axilla of pectoral fin and ventral margin of postcleithral process with multiple large pores in triangular patch tapering posteriorly, finishing short of ventral posterior corner of process.

Dorsal fin I,6; pectoral fin modally I,9*, range I,7-10; pelvic fin i,6; anal fin modally v,9, range iv-v, 7-10 (holotype iv, 10 ); caudal fin $\mathrm{i}, 7 / 8, \mathrm{i}$ (erroneously reported as $\mathrm{i}, 8 / 9, \mathrm{i}$ for Leptodoras in Sabaj, 2005) with dorsal procurrent rays modally $16^{*}$, range $12-19$, and ventral procurrent rays modally $15^{*}$, range $12-18(\mathrm{n}=47$ for all counts $)$. Dorsal-fin origin located approximately one-third of SL from snout tip. Dorsalfin spine strong, compressed, gently curved over entire length and gradually tapered to sharply pointed ossified tip (dorsal-spine tip deformed in holotype); anterior margin weakly serrated along basal half $(<110 \mathrm{~mm} \mathrm{SL})$ to two-thirds ( $>120 \mathrm{~mm} \mathrm{SL}$ ), anterior serrations antrorse, crowded and acute 


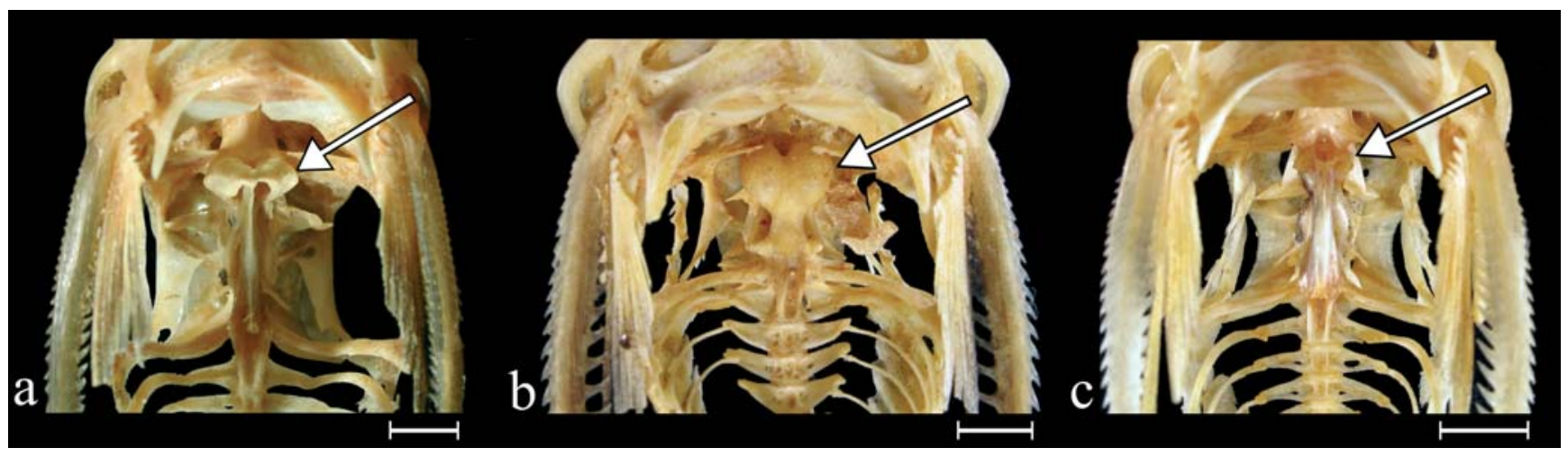

Fig. 6. Anteriormost vertebrae, in ventral view, showing the bony capsules (arrows) of (a) Anduzedoras oxyhynchus, ANSP178551, $138 \mathrm{~mm} \mathrm{SL}$, and (b) Leptodoras cataniai, ANSP 179242, $157 \mathrm{~mm} \mathrm{SL}$, and cup-like expansions in (c) Leptodoras oyawakai, ANSP 187336, $120 \mathrm{~mm}$ SL. Scale bar $5 \mathrm{~mm}$.

basally, becoming gradually more spaced, less acute and smaller distally; posterior margin weakly serrated along distal two-thirds, posterior serrations weakly retrorse, similar in size to anterior ones but more spaced and becoming gradually smaller towards tip and towards base. Adipose fin tear-drop shaped with rounded free distal margin; base not continued

Table 1. Morphometric data for Leptodoras oyakawai $(\mathrm{Hol}=$ holotype).

\begin{tabular}{|c|c|c|c|c|}
\hline & n Mean & Range & SD & Hol \\
\hline Standard length (mm) & 47 & $55.1-123.5$ & & 120.5 \\
\hline \multicolumn{5}{|c|}{ Percents of standard length } \\
\hline Head length & 4732.79 & $30.60-34.81$ & 1.18 & 30.98 \\
\hline Predorsal distance & 4738.84 & $36.01-40.94$ & 1.33 & 37.67 \\
\hline Dorsal origin - adipose distance & 4739.95 & $36.33-43.93$ & 1.66 & 42.67 \\
\hline Adipose - caudal distance & 4725.39 & $21.90-28.20$ & 1.32 & 23.40 \\
\hline Prepectoral distance & 4729.26 & $26.87-32.71$ & 1.18 & 27.83 \\
\hline Pectoral - pelvic distance & 4720.60 & $18.26-24.72$ & 1.49 & 24.72 \\
\hline Pelvic - anal distance & 4724.87 & $21.93-28.41$ & 1.47 & 22.42 \\
\hline Anal - caudal distance & 4728.22 & $24.95-30.87$ & 1.12 & 24.95 \\
\hline Dorsal-fin spine length & 4721.93 & $19.15-27.66$ & 1.50 & 24.26 \\
\hline Pectoral-fin spine length & 4621.19 & $18.43-24.87$ & 1.23 & 22.93 \\
\hline Pelvic-fin length & 4715.46 & $12.92-17.57$ & 1.07 & 13.92 \\
\hline Anal-fin base length & 4713.41 & $11.55-14.35$ & 0.65 & 13.37 \\
\hline Body depth & 4718.52 & $17.38-20.17$ & 0.70 & 19.79 \\
\hline Caudal peduncle depth & $47 \quad 5.47$ & $4.72-6.17$ & 0.32 & 6.12 \\
\hline \multicolumn{5}{|c|}{ Percents of predorsal distance } \\
\hline Head length & 4784.42 & $80.48-86.69$ & 1.47 & 82.23 \\
\hline Adipose eye distance & 4727.79 & $25.57-29.88$ & 1.11 & 26.89 \\
\hline Snout length & 4736.70 & $34.10-39.42$ & 1.41 & 37.59 \\
\hline Snout - anterior nares distance & 4717.97 & $14.31-21.24$ & 1.71 & 16.78 \\
\hline Snout - posterior nares distance & 4731.52 & $29.12-34.92$ & 1.22 & 31.27 \\
\hline Snout - posterior orbit distance & 4762.43 & $59.90-66.14$ & 1.42 & 62.26 \\
\hline Anterior nares - posterior orbit distance & 4744.02 & $40.59-47.90$ & 1.56 & 46.11 \\
\hline Posterior nares - posterior orbit distance & 4730.95 & $28.18-33.32$ & 0.93 & 31.45 \\
\hline Internares distance & 4712.06 & $10.33-15.73$ & 1.20 & 12.66 \\
\hline Postorbital length & 4742.50 & $39.73-46.54$ & 1.58 & 44.42 \\
\hline Cleithral posterior process length & 4717.81 & $13.21-24.27$ & 2.49 & 22.48 \\
\hline Jaw - upper labial extension distance & 4522.31 & $15.93-27.56$ & 2.37 & 18.92 \\
\hline Head width & 4743.73 & $38.02-51.22$ & 3.13 & 51.22 \\
\hline Cleithral width & 4747.18 & $42.66-53.25$ & 2.16 & 53.25 \\
\hline Interorbital width & 479.93 & $6.99-13.92$ & 1.61 & 13.87 \\
\hline Gape width & 4710.82 & $9.06-12.83$ & 0.82 & 10.94 \\
\hline \multicolumn{5}{|c|}{ lepth at } \\
\hline
\end{tabular}

Scute depth from 10th scute anteriorly as fleshy keel; origin slightly posterior to anal-fin origin. Pectoral-fin spine strong, dorsoventrally flattened, gently curved over entire length and gradually tapered to sharply pointed ossified tip; length and shape similar to that of dorsal spine; adpressed tip approximately reaching vertical through pelvic-fin origin; anterior margin moderately serrated for entire length or distalmost tip sometimes smooth, anterior serrations antrorse becoming gradually larger towards midlength, then smaller and less acute towards tip; posterior margin with slightly larger retrorse serrations for entire length, posterior serrations largest near midlength, becoming much smaller towards base and slightly smaller towards tip. Pelvic fins subtriangular, distal margin straight to weakly rounded and perpendicular to longitudinal axis when moderately extended; origin slightly posterior to posterior base of dorsal fin, and anterior to midpoint of SL in smaller specimens $(<110$ $\mathrm{mm} \mathrm{SL})$ becoming closer to midpoint in larger specimens $(>120$ $\mathrm{mm} \mathrm{SL}$ ). Anal fin large, triangular with extended distal margin straight to weakly concave, angled ventroanteriorly. Caudal fin forked with lobes approximately equal; lobes weakly rounded in adults, more pointed in juveniles. Upper and lower procurrent caudal-fin rays like those of caudal fin, not modified into plates.

Lateral line ossified with complete series of 33 (1), 34 (6), 35 (36), 36* (21) or 37 (3) midlateral scutes per side, beginning with infranuchal. Sum of both sides: 67 (1), 68 (1), 69 (6), 70 (5), $71 *(16), 72$ (12), 73 (2) or 74 (2). Lateral line in tympanic region (delimited by infranuchal scute, nuchal shield and postcleithral process) with three separate ossifications decreasing in size anteriorly to posteriorly, and largely covered by skin except for small emergent thorn; anteriormost ossification elongate and plate-like, posteriormost one highly reduced and sometimes lacking thorn. Infranuchal scute tall with well-developed laminar wings above and below medial ridge or weak thorn; anterior margin embedded in skin; posterior margin exposed, strongly serrated with deep central notch separating dorsal and ventral wings; dorsal wing firmly attached to posterior nuchal plate dorsally; ventral wing me- 


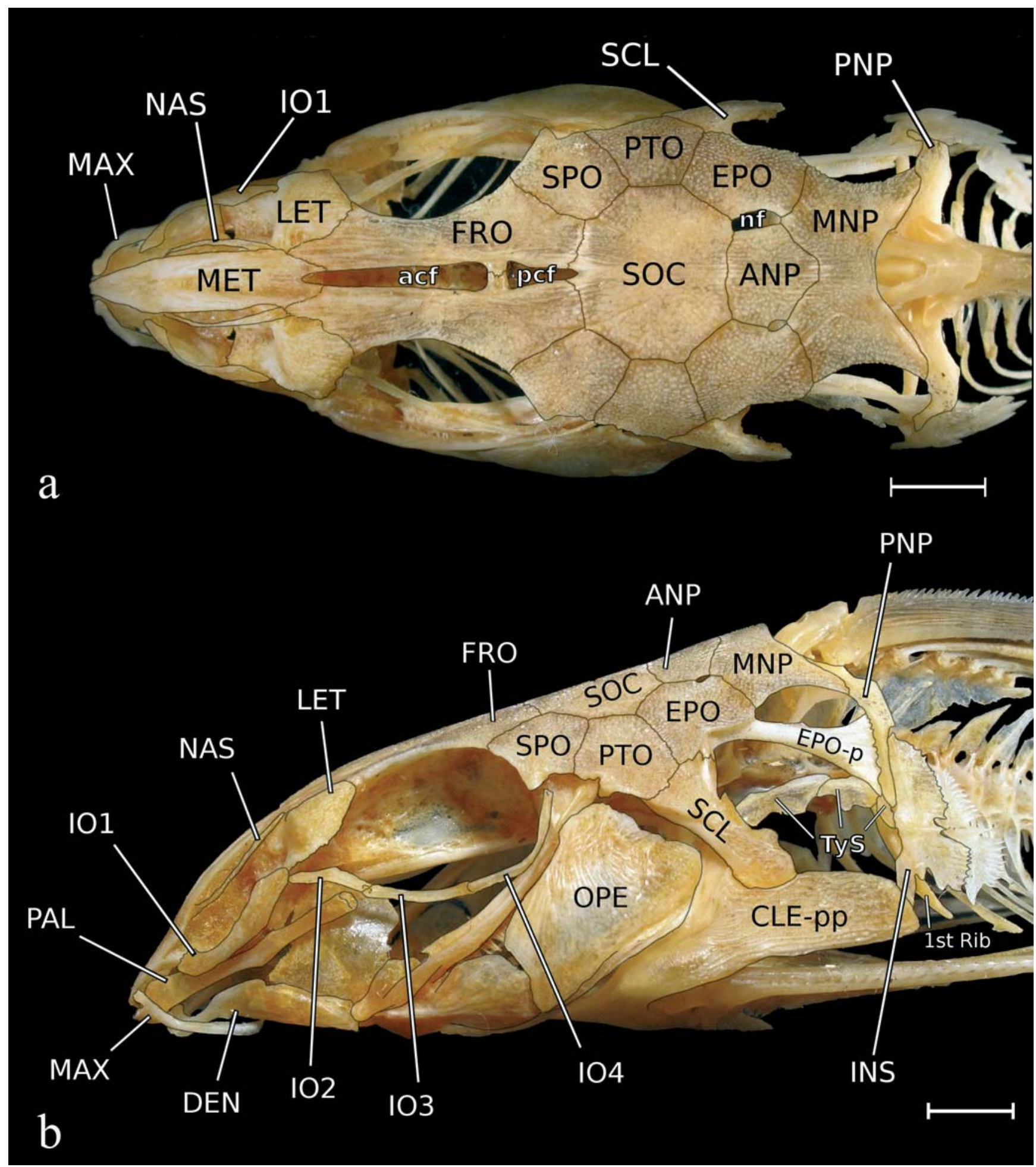

Fig. 7. Head of Leptodoras oyakawai, ANSP 187336, paratype, $120 \mathrm{~mm} \mathrm{SL}$, in (a) dorsal and (b) lateral (left side) views. acf anterior cranial fontanel, ANP anterior nuchal plate, CLE-pp postcleithral process, DEN dentary, EPO epioccipital, EPO-p epioccipital posterior process, FRO frontal, INS infranuchal scute, IO1-4 infraorbitals, LET lateral ethmoid, MAX maxilla, MET mesethmoid, MNP middle nuchal plate, NAS nasal, nf nuchal foramina, OPE opercle, pcf posterior cranial fontanel, PNP posterior nuchal plate, PAL autopalatine, PTO pterotic, SOC parieto-supraoccipital, SCL posttemporal-supracleithrum, SPO sphenotic, TyS tympanal scutes. Scale bar $5 \mathrm{~mm}$. 
dially attached to first rib (borne on sixth vertebra) and underlying distal margin of postcleithral process anteroventrally (Fig. 7b). Postinfranuchal scutes oblique and strongly overlapping, depth uniform to anal-fin origin, then becoming gradually shallower to caudal-fin base; depth of scutes above pelvic-fin origin one-fourth to one-fifth of corresponding body depth. Each postinfranuchal scute with subtriangular dorsal and ventral wings above and below distinct medial thorn curved posteriorly; posterior margins of wings distinctly serrated; dorsal wing drawn out anterodorsally into point, ventral wing similarly drawn out posteroventrally. Infranuchal scute with dorsal wing weakly overlying that of first postinfranuchal scute.

Gas bladder moderately sized, occupying most of anterodorsal portion of visceral cavity; external wall (tunica externa) thin and smooth, without diverticula; internal Tshaped septum well-developed, completely divides posterior half into separate chambers which are partially separated from single anterior chamber (Fig. 5). Gas bladder in juveniles much wider than long with broad anterior chamber (total width 1.6 and 1.7 times total length in specimens $89 \mathrm{~mm}$ and $50.3 \mathrm{~mm} \mathrm{SL}$, respectively; Figs. 5a-b). In adults posterior chambers become relatively larger (total bladder width about equal to total length in specimen $121.7 \mathrm{~mm} \mathrm{SL}$ ) and together with broader anterior chamber impart acorn-like shape to entire bladder (Fig. 5c-f). Müllerian windows subcircular, deeply inserted on anterior wall of gas bladder, approaching vertical in transverse plane.

Osteology. Mesethmoid shaped like a fountain pen nib, very elongate (length about 7 times width), posterior sides more or less parallel to transverse line across anterior tips of nasal bones, anterior sides gradually converging to narrow tip with minute notch; posteriorly with V-shaped notch enclosing anterior cranial fontanel (Fig. 7a). Lateral ethmoid elongate; posterior half superficial, forming significant portion of anterior border of orbit; dorsomedially sutured to frontal and mesethmoid aside small intervening gap, and anteroventrally attached to first infraorbital (lacrimal). Nasal very thin, long, and unbranched. First infraorbital (lacrimal) elongate and not contributing to orbital perimeter (Fig. $7 b$ ); medial margin with broad concavity for anterior naris; anterior and posterior wings similarly sized or posterior wing slightly larger; both wings moderately long, pointed; posterior wing remote from orbit. Second, third and fourth infraorbitals canal-like, thin and long, completing ventral perimeter of orbit between first infraorbital and anterolateral corner of sphenotic; fourth infraorbital longest, L-shaped. Frontal elongate, narrow, completing dorsalmedial perimeter of orbit. Cranial fontanel long and very narrow, with anterior and posterior openings separated by epiphyseal bar slightly anterior to point where frontal-sphenotic suture meets orbital rim. Anterior cranial fontanel longer, length 2-3 times that of posterior fontanel, enclosed anteriorly by small Vshaped notch in mesethmoid and laterally by frontals; pos- terior fontanel narrowly triangular, pointed posteriorly, enclosed laterally by frontals and posteriorly by small notch in parieto-supraoccipital. Parieto-supraoccipital octagonal, slightly broader than long, surrounded by frontals, sphenotics, pterotics, epioccipitals, and anterior nuchal plate. Sphenotic subpentagonal with acute anterolateral corner attached to fourth infraorbital. Pterotic subpentagonal, posterior ventral margin sutured to posttemporal-supracleitrum. Epioccipital roughly quadrangular to pentagonal, with externally visible sutures to pterotic anteriorly, parieto-supraoccipital and sometimes anterior nuchal plate medially and middle nuchal plate posteriorly; suture to posttemporalsupracleitrum largely internal except for very short portion visible externally. Epioccipital posterior process well developed, ossified to posterior nuchal plate; laminar with lateral vertical portion curving smoothly and ventrally inwards as horizontal shelf; process relatively narrow anteriorly, becoming gradually expanded posteriorly, particularly in vertical plane. Anterior nuchal plate well developed, subpentagonal (pointed posteriorly), wider than long. Middle nuchal plate large, somewhat butterfly-shaped; lateral margins concave; anterior margin remote from parietosupraoccipital and with broad V-shaped notch for anterior nuchal plate. Posterior nuchal plate narrow, ventrally elongated to point near third tympanal ossification with ventral posterior margin attached to infranuchal scute; superficial portion ornamented as remaining nuchal shield. Nuchal shield roof-shaped, more so posteriorly (forming about $90^{\circ}$ angle); with narrow medial groove in smaller specimens, becoming obsolete in adults. Nuchal foramina usually present; opening as long slit-like fissure between anterior nuchal plate and epioccipital that may be partially or completely occluded, replaced by suture between same bones in larger specimens ( $\mathrm{SL} \geq 96 \mathrm{~mm}$ ).

Cranium in ventral view with prevomer elongate, slightly expanded anteriorly but without distinct (acute) anterolateral processes. Parasphenoid narrow, distinctly elevated from skull roof (in ventral view) by interorbital septum formed in large part by adpressed orbitosphenoids. Basioccipital with short lateral arms firmly sutured to ossified transcapular (Baudelot's) ligament. Ossified transcapular ligament flattened anteroposteriorly and broadly expanded ventrally; ventral margin rounded, entire except for transverse notch(es) in medial side, usually deep and narrow; sometimes with small foramina in center of ossified ligament.

Premaxilla edentulous, subtriangular, with medial margin attached to ventral keel of mesethmoid by connective tissue, and lateral point expanded by elongate rod of cartilage or connective tissue contributing to oral hood. Maxilla elongate and curved, proximal end bifurcated into two condylar processes articulating with complex facet formed by mesethmoid, premaxilla and cartilaginous head of autopalatine. Autopalatine long, rod-like; central portion narrow with weak process for articulation with shallow cartilaginous facet formed by first infraorbital, mesethmoid and 
lateral ethmoid; bone becoming gradually larger towards either end both of which are capped with cartilage. Dentary edentulous, elongate, posteriorly sutured to anguloarticular (Fig. 8); anterior portion tooth-brush-like, posterior portion trapezoidal. Remnant of Meckelian cartilage L-shaped with vertical arm forming cartilaginous coronoid process. Quadrate relatively broad, anteriorly with condylar region for articulation with lower jaw; joined ventrally to preopercle, anterodorsally to metapterygoid and posterodorsally to hyomandibula via cartilage. Metapterygoid small, triangular with anterior and dorsal sides enclosed by mesopterygoid. Mesopterygoid larger, contacting lateral ethmoid. Hyomandibula elongate, relatively narrow and gently curved for entire length, lacking contact anteriorly with metapterygoid. Preopercle long and very narrow, dorsal margin attached quadrate (anteriorly) and hyomandibula (posteriorly). Interopercle relatively large, roughly trapezoidal. Opercle roughly triangular, firmly attached by connective tissue to lateral border of pterotic.

Urohyal small (Fig. 9), with well-developed ventral process. Ventral hypohyal large, joined to anterior ceratohyal via cartilage and short suture; dorsal hypohyal much smaller, arched. Small fenestra enclosed by ventral hypohyal anteriorly and dorsal hypohyal posteriorly. Anterior ceratohyal large, expanded posteriorly, and joined to posterior ceratohyal via cartilage. Seven branchiostegal rays, five attached to anterior ceratohyal and two to interceratohyal cartilage.

Five branchial arches (Fig. 10). Three basibranchials (first one absent); basibranchials two and three elongate, ossified with cartilaginous caps; fourth one longest, cartilaginous. Three hypobranchials; first and second ones elongate, ossified with cartilaginous caps; third one short and broad, cartilaginous, medially attached between basibranchials three and four. Five ceratobranchials; first four narrow, elongate, ossified with cartilaginous caps; dorsal half of cartilaginous cap of fourth ceratobranchial expanded anteriorly as narrow process aside fourth

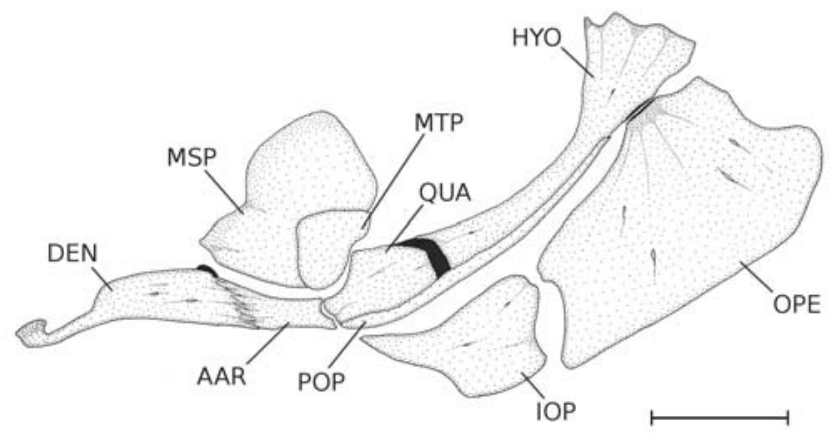

Fig. 8. Suspensorial and opercle series in Leptodoras oyakawai, based on MZUSP 95722, $73 \mathrm{~mm} \mathrm{SL}$, in lateral view. AAR anguloarticular, DEN dentary, HYO hyomandibula, IOP interopercle, MSP mesopterygoid, MTP metapterygoid, OPE opercle, POP preopercle, QUA quadrate. Scale bar $5 \mathrm{~mm}$. basibranchial; fifth ceratobranchial with extremely narrow proximal stalk and triangularly expanded distal portion bearing single medial row of about 10 acicular teeth. Five epibranchials; first four elongate, ossified with cartilaginous

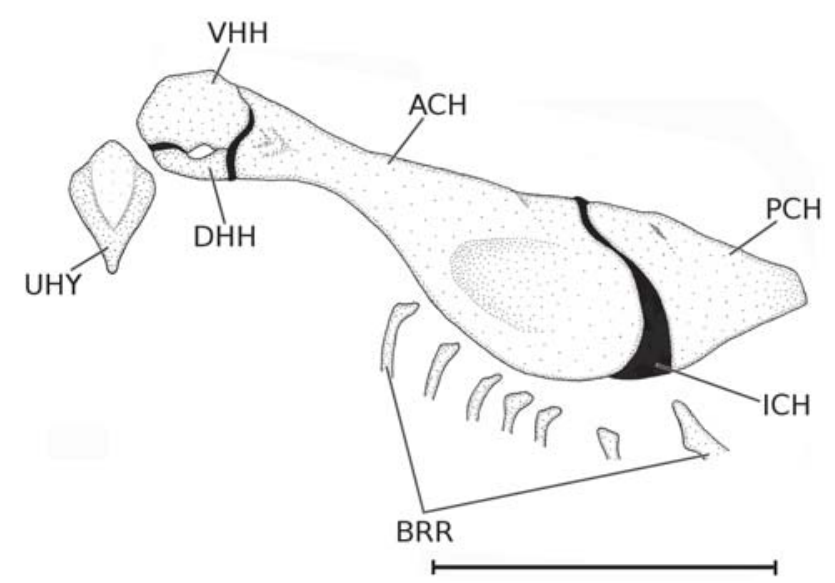

Fig. 9. Hyoid arch of Leptodoras oyakawai, based on MZUSP 95722, $73 \mathrm{~mm} \mathrm{SL}$, in ventral view. ACH anterior ceratohyal, BRR branchiostegal rays, DHH dorsal hypohyal, ICH interceratohyal cartilage, $\mathrm{PCH}$ posterior ceratohyal, UHY urohyal, VHH ventral hypohyal. Scale bar $5 \mathrm{~mm}$.

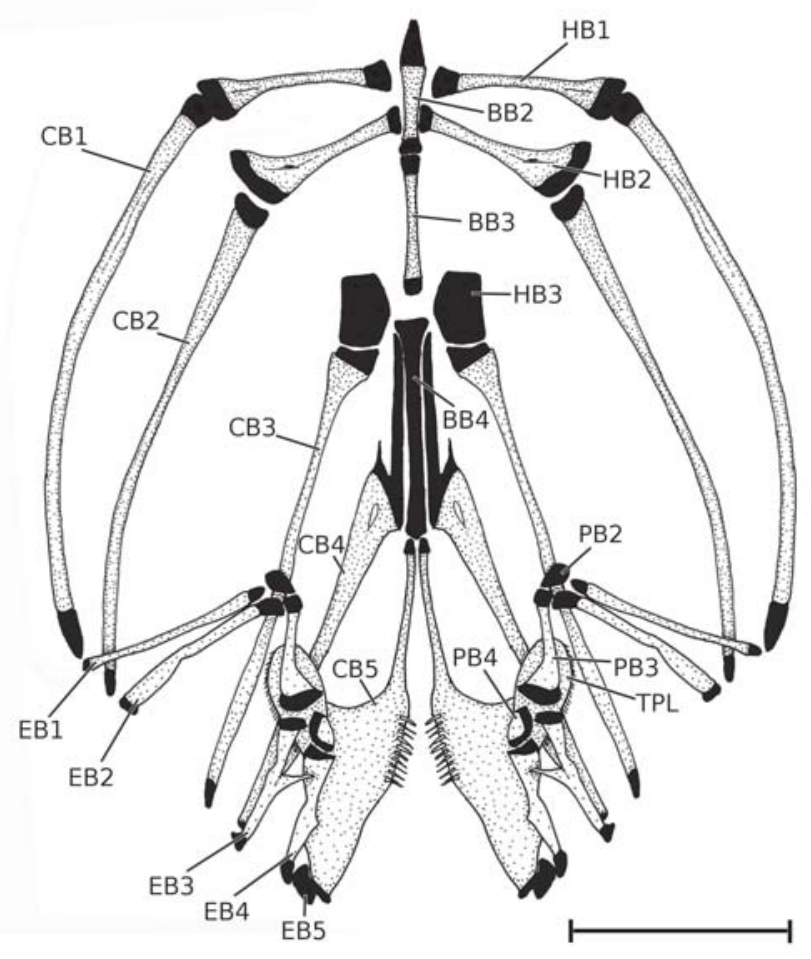

Fig. 10. Branchial skeleton of Leptodoras oyakawai, based on MZUSP 95722, $73 \mathrm{~mm} \mathrm{SL}$, in dorsal view. BB2-4 basibranchials, CB1-5 ceratobranchials, EB1-5 epibranchials, HB1-3 hypobranchials, PB2-4 pharingobranchials, TPL tooth plate. Scale bar $5 \mathrm{~mm}$. 
caps; third one with small posterior process; fifth one small, rod-like, cartilaginous. Three pharyngobranchials; first one small, rectangular, cartilaginous, connected to first two epibranchials and second pharyngobranchial; second pharyngobranchial elongate, ossified with cartilaginous caps; third pharyngobranchial small, ossified portion semicircular with rounded margin capped in cartilage, connected to second pharyngobranchial and third and fourth epibranchials and supporting elongate, lenticular plate with many long acicular teeth.

Pectoral girdle in ventral view subtriangular, elongated anteriorly with broad (obtusely) pointed tip; lateral (convergent) margins shallowly concave (Fig. 11). Coracoid posterior process short, barely surpassing posterior base of pectoral fin. Ventral surfaces of pectoral girdle, including posterior processes of coracoid, concealed by skin (not visible externally). Abductors superficialis and arrector ventralis muscles separated by oblique bony crest on ventral surface of coracoid; crest oriented about $45^{\circ}$ from longitudinal.

Postcleithral process moderately elongate, obliquely truncated posteriorly; dorsal margin shallowly concave opposite posttemporal-supracleithrum, then more or less straight for short distance before curving ventrally to distinct posteroventral corner; ventral margin straight. Surface ornamented with fine, longitudinal ridges becoming more broken and sometimes loosely reticulated posteriorly; ornamentation sometimes separable into two longitudinal fields (wide dorsal and narrow ventral) by continuous subventral ridge. Entire postcleithral process laterally compressed, thickness nearly uniform (i.e., blade-like), without distinct longitudinal swelling or thickening along medial face.

Basipterygium of pelvic girdle subtriangular with four processes: two anterior, one lateral and one posterior (Fig. 12). Anterior processes long and thin, ossified with cartilaginous caps; lateral (outer) one paralleling longitudinal body axis,

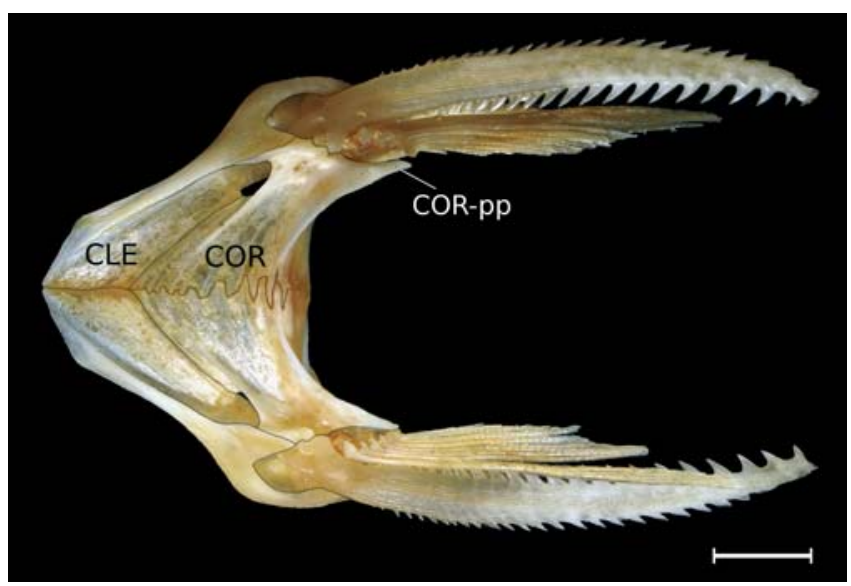

Fig. 11. Pectoral girdle of Leptodoras oyakawai, MZUSP 95722, $73 \mathrm{~mm}$ SL, in ventral view. CLE cleithrum, COR coracoid, COR-pp coracoid posterior process. Scale bar $5 \mathrm{~mm}$. slightly longer and more robust than medial (inner) anterior process, and with small hook-like keel on dorsal surface near base; inner anterior process oblique, convergent but separate with pair, oriented about $30^{\circ}$ from outer process. Lateral process small, pointed anteriorly, extending short distance beyond fin-ray insertions and capped in cartilage along lateral margin. Posterior process short and broad (trapezoidal) with obliquely truncated posterior margin; largely ossified except for cartilaginous cap along medial and posterior margins.

Total vertebrae 38 (2) or 40 (1) with compound caudal centra (PU1 + U1) counted as one and complex vertebra (2-4) completely fused to fifth vertebra, partially fused to sixth, and weakly incorporating seventh (i.e., intervertebral disk between sixth and seventh vertebrae reduced, obscured by ventral superficial ossifications); first normal intervertebral

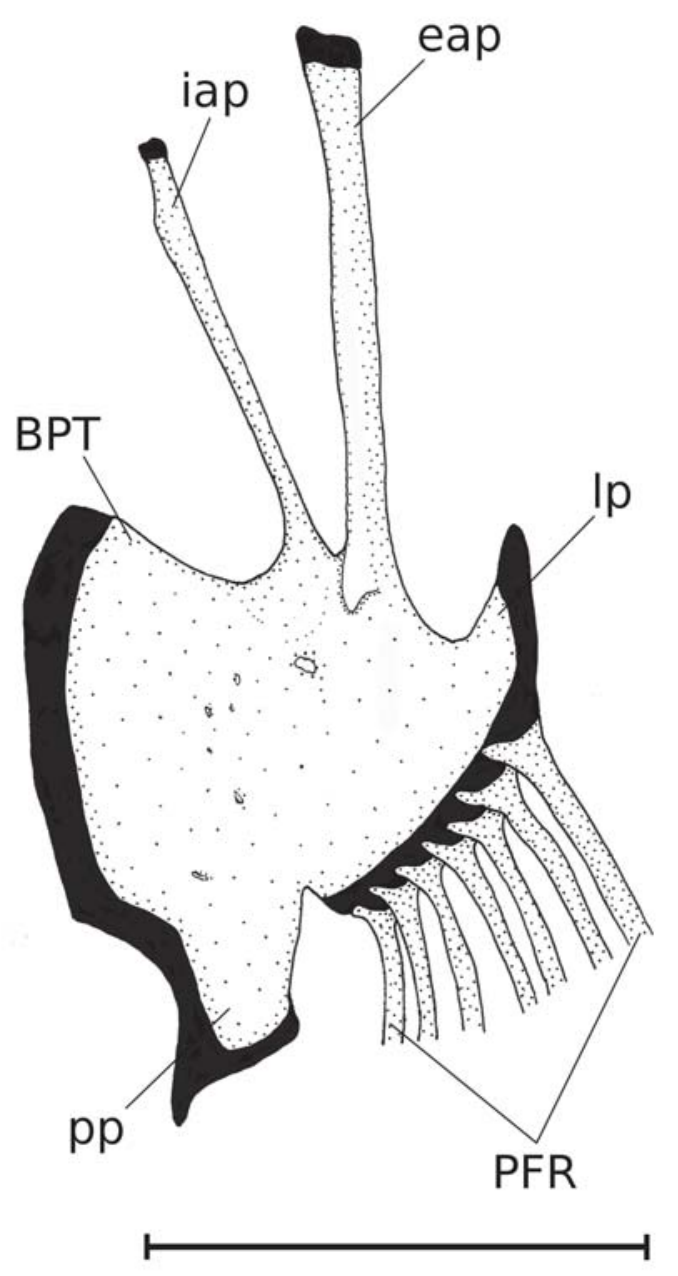

Fig. 12. Pelvic girdle of Leptodoras oyakawai, based on MZUSP 95722, $73 \mathrm{~mm}$ SL, in dorsal view. BPT basipterygium, eap external anterior process of BPT, iap internal anterior process of BPT, lp lateral process of BPT, PFR pelvic-fin rays, $p \mathrm{p}$ posterior process of BPT. Scale bar $5 \mathrm{~mm}$. 
joint between seventh and eighth vertebrae. Complex vertebra (2-4), and perhaps first vertebra, covered ventrally and laterally by superficial ossifications completely enclosing aortic passage and with paired laminar expansions. Anterior portion of lamina nearly vertical and transversely aligned, cup-shaped with concave surface completing anterior wall of gas bladder (between Müllerian windows), and separated from its pair by triangular longitudinal keel. Posteriorly lamina becoming more horizontal, planar and obliquely oriented in transverse plane, expanded from dorsal portion of complex centrum, and completing tunica externa of gas bladder dorsomedially between left and right halves of anterior chamber. Fourth vertebra supporting relatively small, elongate Müllerian ramus, without distal disk-like expansion, but with prominent cartilaginous cap. Fifth vertebra with slender parapophysis directed posteriorly. Sixth vertebrae bearing first pair of ribs joined laterally to medial face of infranuchal scute. Ribs 6 (1) or 7 (2), borne on successive vertebrae. Caudal skeleton with parhypural partially fused to hypural $1+2$ (first and second hypurals completely fused); two separate dorsal hypurals, $3+4$ (fused) and 5, the latter closely associated with urostyle.

Coloration. Ground color tan on dorsal half of head and body. Ground color of lower sides and ventral surfaces pale white with faint dusky gray swath below scutes attenuated posteriorly above anal fin. Faint wide dusky gray stripe above midlateral thorns from infranuchal scute to caudal fin and confluent with its pair dorsally across caudal peduncle; faint broad dusky gray middorsal stripe from dorsal to adipose fins; pale white midlateral stripe along thorns and ventral wings of scutes from infranuchal onto caudal fin. Paired and anal fins pale except for some scattered dark pigment on anteriormost rays and membranes of pectoral fins. Adipose fin with dusky gray base and narrow pale margin. Caudal fin with two dark longitudinal stripes, one on each lobe, narrowly separated by pale midlateral stripe. Dorsal fin pigmentation variable. Jamanxim specimens (middle Tapajós, type series) with distinct dusky black triangular blotch on base of dorsal fin (Fig. 2a). Specimens from the rio Teles Pires (upper Tapajós) and upper Xingu with dark pigment largely limited to proximal third of anterior margin of dorsalfin spine, and with triangular basal blotch narrower, more faint or sometimes absent from remaining fin; in same specimens the dusky middorsal stripe is more faint or absent (Fig. 2b). Live coloration similar to above except dusky stripes less evident; ground color tinted olive; and longitudinal iridescences evident above midlateral scutes from infranuchal to below adipose fin in specimen from upper Xingu (Fig. 2b).

Distribution and Habitat. Leptodoras oyakawai is known from rio Jamanxim (type series) and rio Teles Pires, rio Tapajós basin, and rio Culuene and rio Curisevo, upper rio Xingu basin (Fig. 13). Nearly all specimens were collected during the dry season when water levels were lowest (late September to October). Jamanxim specimens were collected at night on a large sandy shoal where the main channel was wide and shallow (depth less than $2 \mathrm{~m}$ ) and current sluggish. The rio Culuene and rio Teles Pires specimens were collected at night along a sandy beach aside the main channel in moderate current.

Etymology. Named in honor of Osvaldo Takeshi Oyakawa, for his dedicated service to the ichthyological community since 7 July 1989 as Collection Manager of the Fish Collection ("Seção de Peixes") at the Museu de Zoologia da Universidade de São Paulo.

\section{Discussion}

Morphology of bony capsules. The most striking morphological synapomorphy for the sister group relationship between Leptodoras and Anduzedoras (Higuchi, 1992; Sabaj, 2002; Moyer, et al. 2004; Birindelli, 2006) is the development of a pair of conjoined bony capsules on the ventral surface of the anteriormost vertebrae (Fig. 6a-b). As in other doradids the first vertebra becomes wider (flares out) anteriorly and shares a relatively broad suture with the basioccipital. Posterior to the suture between the first vertebra and basioccipital and to the entrance of the ossified aortic tunnel in Anduzedoras and Leptodoras (except in L. oyakawai) there is a pair of rounded

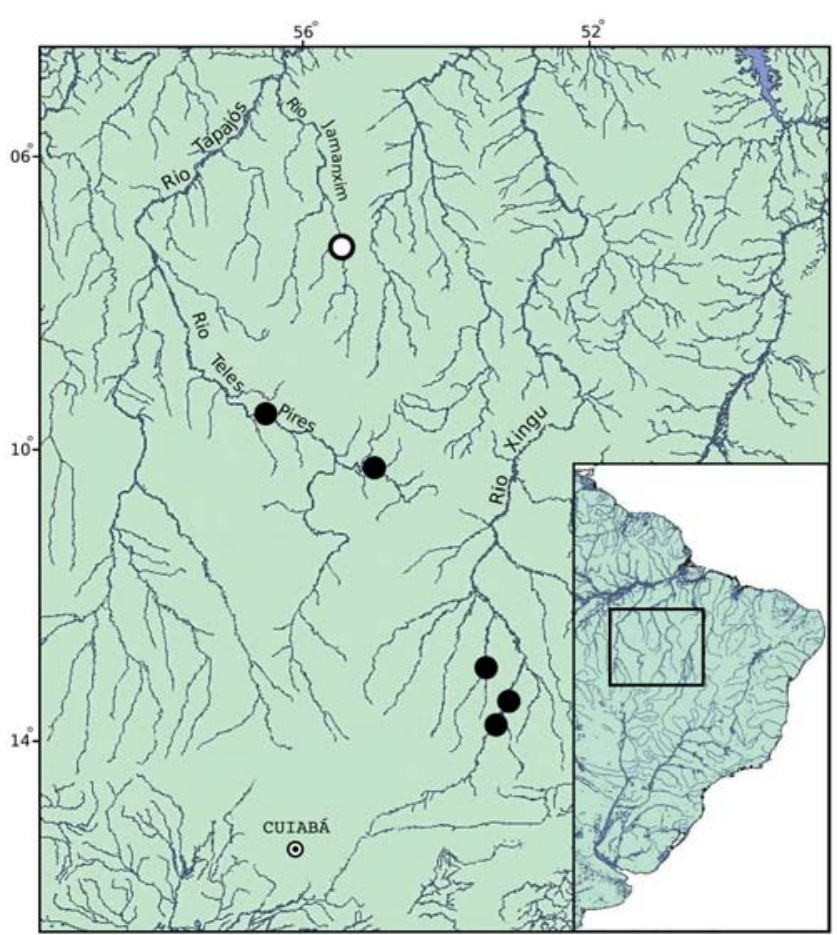

Fig. 13. Distribution of Leptodoras oyakawai in Tapajós and Xingu basins, central Brazil (type locality represented by open circle). 
bony capsules medially separated by a vertical septum that continues posteriorly onto the ventral face of the compound centrum (fused centra 2-4). The capsules appear to be laminar continuations of superficial ossifications covering the compound centrum and obscure its suture to the first vertebra. Aside the bony septum, each capsule has a rounded to vertically elongate opening that faces posteriorly, posterolaterally, or posterodorsally. The rims of the capsules are firmly attached to the tunica externa of the gas bladder such that removal of gas bladder results in a large rounded gap in the anterior wall between the Müllerian windows. The capsules are lined with a thin membrane presumed to be the tunica interna, and the lumen of capsules appears to be continuous with that of the anterior chamber of gas bladder. In Anduzedoras (Fig. 6a), the capsules are more vertically aligned, transversely widened, subtriangular in posterior view and compressed anteroposteriorly. In Leptodoras (Fig. 6b), except in L. oyakawai, the capsules are deflected ventroposteriorly, longitudinally expanded, rounded in posterior view and more bulbous, not compressed anteroposteriorly.

Leptodoras oyakawai presents an intriguing condition wherein the bony capsules are lacking as such, however, putative remnants persist (Fig. 6c). The superficial ossifications covering the compound centrum have paired ventral laminar expansions in the same anterior position as the roof and anterior walls of the bony capsules in other Leptodoras. The ventral laminar expansions are cup-like with concave posterior faces separated by a thin triangular septum. A similar septum is not found outside of Anduzedoras and Leptodoras and thereby helps to establish homology between the true capsules of these taxa and the cup-like laminar expansions in L. oyakawai. This homology is further supported by the relationship between the cup-like laminae to the anterior wall of the gas bladder. As in taxa with true capsules, in $L$. oyakawai the rims of the cup-like laminae are firmly attached to the tunica externa of the gas bladder.

Morphology of anterior nuchal plate and nuchal foramina. A feature of Leptodoras praelongus, shared with Anduzedoras oxyrhynchus, is the reduction of the anterior nuchal plate and its circumscription by the parieto-supraoccipital and middle nuchal plate (Higuchi, 1992; Sabaj, 2002; Birindelli, 2006). In most adults of $L$. copei and $L$. hasemani, however, the anterior nuchal plate is laterally expanded, and shares a broad suture with the epioccipital. In more derived Leptodoras the suture between the anterior nuchal plate and epioccipital appears to be completely or partially replaced by an elongate foramen. In L. oyakawai the anterior nuchal plate is laterally expanded, unlike in L. praelongus and A. oxyrhynchus, and a nuchal foramen is usually present. In juveniles it is often a slit-like fissure between the anterior nuchal plate and epioccipital, whereas in adults the foramen becomes partially or completely occluded and a more firm suture is established between the two bones.
Sabaj (2002) observed that, in Anduzedoras, the nuchal foramen was usually positioned at the junction of parietosupraoccipital, epioccipital and middle nuchal plate. He did not report nuchal foramina in the three basalmost Leptodoras (L. praelongus, L. copei and L. hasemani); but, his observations were largely based on adults. Based on our examination of alcohol preserved juveniles, small specimens ( $<60 \mathrm{~mm} \mathrm{SL}$ ) of $L$. praelongus and L. cope $i$ appear to have nuchal foramina in a condition similar to L. oyakawai.

Relationships of Leptodoras oyakawai. Sabaj (2005) diagnosed Leptodoras on the basis of three characteristics unique among doradids: 1) oral hood modified with distinct upper labial extensions having comparatively smooth ventral surface, lateral margins entire, weakly scalloped or fimbriate and without marginal papillae, and interlabial membrane narrow to moderate; 2) first gill arch with enlarged accessory lamellae on medial (postaxial) face of arch extending well onto medial face of gill filaments; and 3) gas bladder greatly reduced with two distinct horn-like diverticula projecting from posterior walls of posterior chambers and a pair of bulbous diverticula projecting from each lateral wall of anterior chamber.

Leptodoras oyakawai exhibits only the first two of these three characteristics, therefore its inclusion within Leptodoras necessitates a re-diagnosis of the genus. Possession of a reduced gas bladder may be a synapomorphy for all species of Leptodoras minus L. oyakawai, leaving the latter as sister taxon to its congeners. In an unpublished phylogenetic study of Leptodoras based on morphology, Sabaj (2002) recovered $L$. praelongus as sister species to $L$. cope $i+$ all other congeners. One of the characters supporting this relationship is the less modified gas bladder in L. praelongus, wherein the pos-

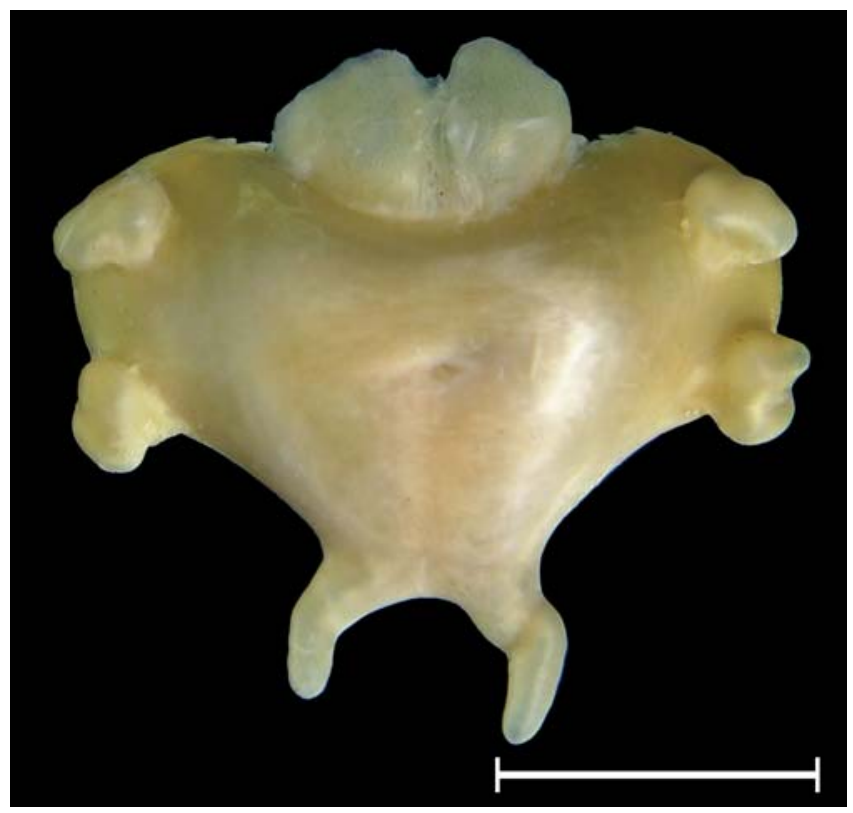

Fig. 14. Gas bladder of Leptodoras copei, ANSP 162461, 96.5 $\mathrm{mm} \mathrm{SL}$, in ventral view. Scale bar $5 \mathrm{~mm}$. 
terior chambers are relatively large, the posterior horns are relatively long, and the pair of anterolateral diverticula appear as large tuberous swellings with highly irregular surfaces (see Fig. 7a in Sabaj, 2005). The gas bladder in Leptodoras copei (Fig. 14) more closely resembles the more derived congeners by having relatively small posterior chambers, short posterior horns and smaller anterolateral diverticula with comparatively smooth surfaces. The gas bladder in L. oyakawai resembles that of Anduzedoras by being moderately sized (not reduced) and lacking distinct posterior horns and anterolateral diverticula; but differs by having smooth walls vs. lateral and posterior walls with small, short diverticulae in Anduzedoras.
Distribution of Leptodoras species. Recent collecting efforts and identifications of museum specimens not studied by Sabaj (2005) have significantly increased the known ranges of many species of Leptodoras (see Comparative Material Examined and Fig. 15). Two of the most interesting range expansions are for L. hasemani and L. linnelli. Leptodoras hasemani was previously known only from drainages north of the Amazon River channel. Its distribution included the main channel and/or lower reaches of tributaries to the Orinoco, Negro, Branco and Essequibo, forming a ring around the western Guiana Shield. The recent expedition to Serra do Cachimbo collected two large adults in the rio Jamanxim in the middle Tapajós, extending the range of this species to the

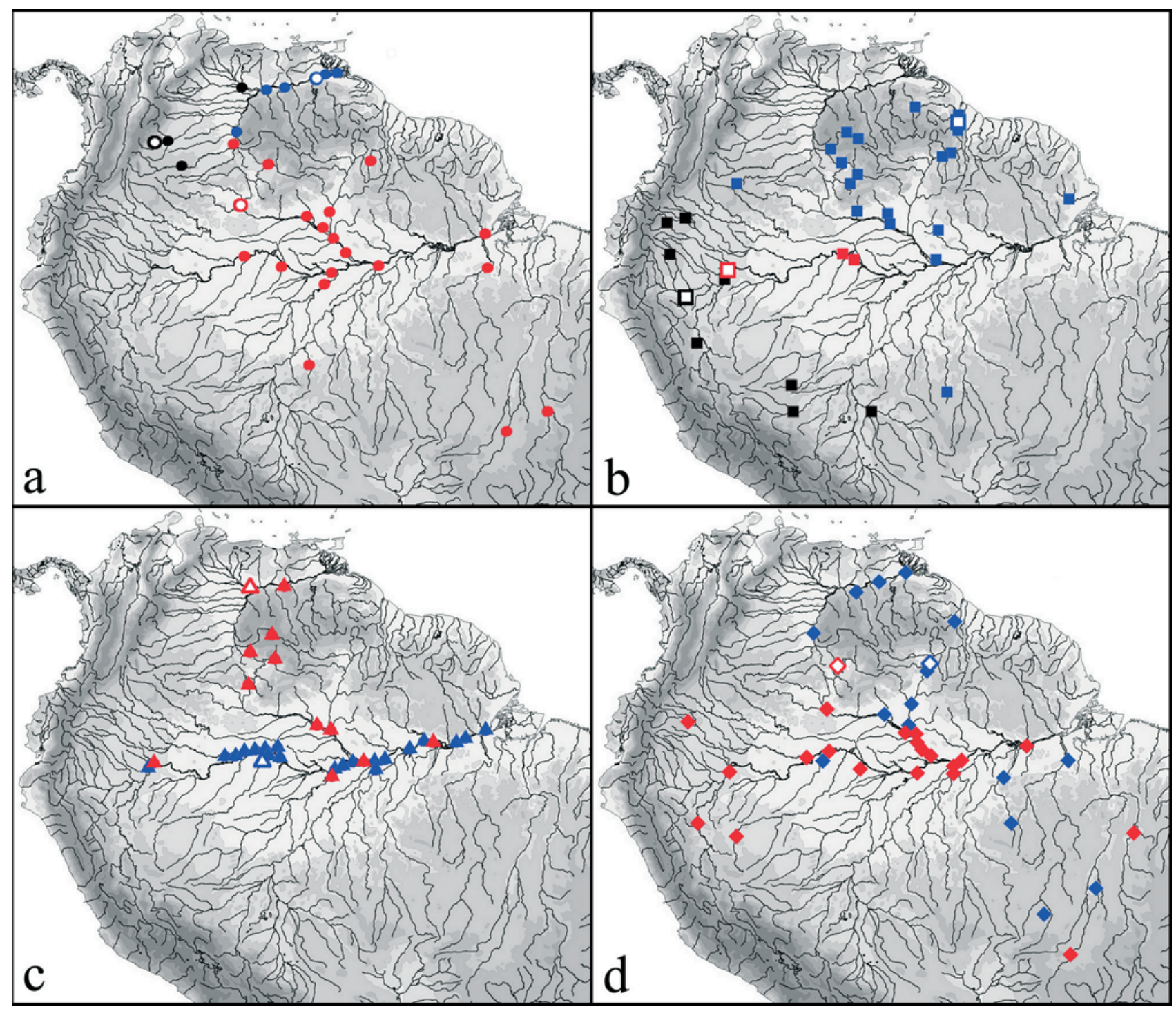

Fig. 15. Distribution of Leptodoras species, based on Sabaj (2005). In a, Leptodoras praelongus represented by red circle, L. nelsoni by black circle, and L. rogersae by blue circle. In b, L. myersi represented by red square, L. acipenserinus by black square, and L. linnelli by blue square. In c, L. copei represented by red triangle, and L. juruensis by blue triangle. In d, L. cataniai represented by red lozenge, and L. hasemani by blue lozenge (type localities represented by opened symbols). 
Brazilian Shield. The former distribution of L. linnelli similarly included only basins north of the Amazon channel and north of the Negro channel, such as the upper Orinoco, Casiquiare, Demini, Uatumã, Essequibo, and Araguari. Recent collecting efforts led by F. C. T. Lima in northwestern Amazonas State, Brazil, discovered L. linnelli in the rio Tiquié basin, a right bank tributary of the upper rio Negro. Collecting efforts by F. A. Machado in Mato Grosso State, Brazil, discovered $L$. linnelli in the upper rio Aripuanã, a tributary of the rio Madeira, extending the known distribution of this species into the western limits of the Brazilian Shield. As in many cases for neotropical fishes, known distributions are often far from complete, even after many field trips and museum visits.

Comparative Material Examined. To the material listed in Sabaj (2005), we add: Anduzedoras oxyrhynchus: Brazil (Amazonas drainage): MZUSP 15763 (1, 165 mm SL), Pará, Igapó do lago Farias, Reserva Biológica de Trombetas, rio Trombetas (012 $\left.25^{\prime} \mathrm{S} 56^{\circ} 37^{\prime} \mathrm{W}\right)$; MZUSP 93443 (2: 147-190 mm SL), Amazonas, rio Tiquié, Serra do Mucura $\left(00^{\circ} 10^{\prime} 00^{\prime \prime} \mathrm{S} 60^{\circ} 07^{\prime} 00\right.$ 'W); MZUSP 81516 (2, 183186 mm SL), Amazonas, rio Tiquié, Amazonas; MZUSP 50383 (3, 228-232 mm SL), rio Negro, Baturité, Amazonas, 28 Apr 1976, Faustino. MZUSP 84764 (1, 228 mm SL), Amazonas, rio Negro $\left(00^{\circ} 21^{\prime} \mathrm{S} 68^{\circ} 27^{\prime} \mathrm{W}\right)$. MZUSP 85359 (1, $270 \mathrm{~mm}$ SL), Amazonas, rio Tiquié, Caruru (00¹6'S 6954'W). MZUSP 29021 (34, 78.4$115.3 \mathrm{~mm} \mathrm{SL})$, Amazonas, rio Negro ( $\left.00^{\circ} 35^{\prime} \mathrm{S} 64^{\circ} 45^{\prime} \mathrm{W}\right)$. MZUSP 29029 (215, 31-92.3 mm SL, 2 cs, 56-92.3 mm SL), Amazonas, Barcelos, rio Negro (0058'S 6257'W). MZUSP 29028 (123, 33.7$56.7 \mathrm{~mm} \mathrm{SL})$, Amazonas, rio Negro, Marauiá (00²4'S 6512'W). MZUSP 29025 (2, 46.9-111.1 mm SL), Amazonas, rio Negro, Urumari (0058'S 62॰57'W). MZUSP 91672 (2, 109.5-114.6 mm SL), Amazonas, rio Uaupés. MZUSP 29022 (2, 105.5-105.7 mm $\mathrm{SL})$, Amazonas, rio Arirará (Negro basin) (00³1'S 633' $\mathrm{W})$. MZUSP 29023 (1, 110.5 mm SL), Amazonas, rio Ariraá (Negro basin) (00³1'S 633' 'W). MZUSP 29021 (2, 74.4-77.5 mm SL),

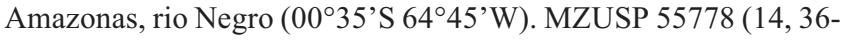
$64.3 \mathrm{~mm} \mathrm{SL})$, Amazonas, rio Negro (0141'13"S 61²7'14”W). MZUSP 56034 (3, 55-65.4 mm SL), Amazonas. MZUSP 55773 (1, $47 \mathrm{~mm}$ SL), rio Negro. MZUSP 56028 (1, $50.6 \mathrm{~mm} \mathrm{SL})$, Amazonas, rio Negro. MZUSP 91454 (2, 205-230 mm SL), Amazonas, Vista Alegre, rio Negro (00²1'S 68 $27^{\circ}$ 'W). MZUSP 91455 (9, 165-205 $\mathrm{mm}$ SL), Amazonas, Tapera, rio Negro (01 ${ }^{\circ} 12^{\prime}$ 'S $\left.64^{\circ} 4^{\prime \prime} \mathrm{W}\right)$. MZUSP 82285 (234, 105-220 mm SL), no data, M. Goulding. Leptodoras acipenserinus: (Amazonas drainage): MCP 35424 (1, $79 \mathrm{~mm} \mathrm{SL}$ ), Roraima, Guarajá Mirim, rio Mamoré. MZUSP 26385 (2, 75-85 mm SL), Peru, Pucallpa, Nuevo Requena, río Aguaytia. MZUSP 49774 (1, 143 mm SL), Brazil, Acre, rio Acre. Leptodoras cataniai: Brazil (Amazonas drainage): MCP 29659 (3, 61-85 mm SL), Amazonas, Tefé, Toco Preto, rio Tefé. MZUSP 50477 (1, 165 mm SL), Brazil, Acre, rio Juruá. MZUSP 56040 (11, 77.5-106.3 mm SL), Amazonas, rio Jutaí (02`53'08'S 6700'25'W). MZUSP 56842 (1, $46.5 \mathrm{~mm} \mathrm{SL})$, Amazonas, rio Negro (02॰59'53”S 60²5'29”W). MZUSP 56864 (1, $48.6 \mathrm{~mm} \mathrm{SL})$, Amazonas, rio Madeira (0339'09”S 59॰03'30”W). MZUSP 56868 (1, $45.3 \mathrm{~mm}$ SL), Amazonas, rio Amazonas (0320'22”S 58³6’31”W). MZUSP 56869 (1, $43.1 \mathrm{~mm} \mathrm{SL})$, Amazonas, rio Madeira (0319'59”'S 58³5'59”W). MZUSP 57302 (1, 66.8 mm SL), Amazonas, rio
Purus (0356'13"S 61²6'47”W). MZUSP 57311 (1, 46.5 mm SL), Amazonas, rio Amazonas (0316'33”S 58 57'03”W). MZUSP 57326 (1, $42.7 \mathrm{~mm} \mathrm{SL})$, rio Amazonas (0319'57'S 58 35'31'W). MZUSP 57979 (1, $49 \mathrm{~mm} \mathrm{SL})$, Amazonas, rio Amazonas (0321'19”'S 5842'02”'W). MZUSP 57983 (1, $37.7 \mathrm{~mm}$ SL), Amazonas, rio Amazonas (0316'35"S 58 56'52”W). MZUSP 58139 (7, 67.5-75.4 mm SL), Amazonas, rio Amazonas. MZUSP 98709 (6, 145-194 mm SL), Amazon basin, probably rio Negro, M. Goulding. MZUSP 88121 (3, 142-164 mm SL), Goiás, Aragarças, rio Araguaia. MZUSP 82978 (2, 91.9-93.6 mm SL), Pará, rio Amazonas (02॰05'49”S 5400'17'W). MZUSP 56039 (6, 74.4$113.2 \mathrm{~mm}$ SL), Amazonas, rio Jutaí (0252’36”S 6659’20”W). MZUSP 31100 (1, $160 \mathrm{~mm}$ SL), Cachoeira de São Gabriel, rio Negro (0007'S 6705'W). MZUSP 55837 (7, 85.4-146.5 mm SL), Amazonas, rio Negro (01 $58^{\circ} 07^{\prime}$ 'S 61 ${ }^{\circ} 14$ '43”W). MZUSP 56239 (2, 66.1-99.9 mm SL), Amazonas, rio Negro (01²3'12"S 6153'49"W). Leptodoras copei: Brazil (Amazonas drainage): MZUSP 57296 (1, $52.4 \mathrm{~mm} \mathrm{SL})$, Amazonas, rio Purus. MZUSP 58078 (2, 53.1-52.4 mm SL), Pará, rio Amazonas (0203'50”S 55²0'47'W). MZUSP 56042 (1, 53.6 mm SL), Amazonas, rio Negro (0146’41'S 61²5'14”W). MZUSP 56245 (2, 41.2-41.6 $\mathrm{mm}$ SL), Roraima, rio Negro (01 23 '12"S 61 53 '49"W). MZUSP 56302 (1, $49.9 \mathrm{~mm} \mathrm{SL})$, Amazonas, rio Negro (0144'26"S 6125'05'W). MZUSP 56306 (6, 43.1-57.9 mm SL), Roraima, Rorainópolis, rio Negro (01³0'49”'S 61³2'18”W). MZUSP 58136 (6, 44.2-62.3 mm SL), Amazonas, rio Negro (0304'39"S $60^{\circ} 10^{\prime} 51$ 'W). Leptodoras hasemani: Brazil (Amazonas drainage): MZUSP 29066 (2, 110.1-129 mm SL), Pará, Belo Monte, rio Xingu (0310’S 51 50 'W). MZUSP 31707 (1, 136.4 mm SL), Pará, Itaituba, rio Tapajós (04 $\left.17^{\prime} \mathrm{S} 55^{\circ} 59^{\prime} \mathrm{W}\right)$. MZUSP 37009 (2, 111-133.5 mm SL), Roraima, Boa Vista, rio Branco (02 $50^{\circ}$ 'S $\left.60^{\circ} 40^{\prime} \mathrm{W}\right)$. MZUSP 53820 (1, $147 \mathrm{~mm}$ SL), Mato Grosso, Ilha do Bananal, rio Araguaia. MZUSP 56678 (1, 99.3 mm SL), Amazonas, rio Jutaí (0257’22’'S 6700’28”W). MZUSP 82300 (11, 135-162 mm SL), Pará, Itaituba, rio Tapajós $\left(04^{\circ} 27^{\prime} \mathrm{S} 56^{\circ} 15^{\prime} \mathrm{W}\right)$. MZUSP 87027 (1, $\left.161 \mathrm{~mm} \mathrm{SL}\right)$, Mato Grosso, Gaúcha do Norte, rio Curisevo, Xingu basin (1302'05”S 5325'19”W). MZUSP 97363 (2, 175-192 mm SL),

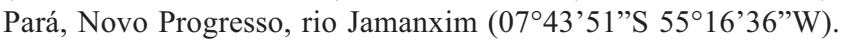
MZUSP 29067 (4, 91.8-116.5 mm SL), Pará, rio Tapajós, between Itaituba and São Luiz. Leptodoras juruensis: Brazil (Amazonas drainage): MZUSP 82985 (1, 121.6 mm SL), Pará, Monte Alegre, rio Amazonas ( $\left.02^{\circ} 05^{\prime} \mathrm{S} 54^{\circ} 00^{\prime} \mathrm{W}\right)$. MZUSP 55834 (2, 108-146 mm SL), Amazonas, rio Solimões (039'7'S 6754'37'W). MZUSP 56157 (2, 90-98 mm SL), Amazonas, rio Solimões (0316’10'S 6443'11'W). MZUSP 57859 (6, 36.6-96 mm SL), Amazonas, rio Amazonas (0316'27'’S 58 56'34'W). MZUSP 55817 (1, $58.5 \mathrm{~mm}$ SL), Amazonas, rio Solimões. MZUSP 57317 (1, 66 mm SL), Pará, rio Amazonas. MZUSP 8765 (1, $108.5 \mathrm{~mm} \mathrm{SL})$, Amazonas, rio Solimões, ilha Mari-Mari. MZUSP 822880 (2, 87.6-117.9 mm SL),

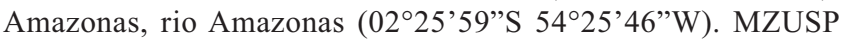
57055 (5, 86.1-127 mm SL), Amazonas, rio Solimões (0311'38'S 6448'28”'W). MZUSP 57054 (10, 104.7-120.4 mm SL), Amazonas, rio Solimões (0311'1'"S 6448'42'W). MZUSP 83324 (16, 70.2176 mm SL), Amazonas, rio Amazonas (0321'20”'S 58³9’32”W). Leptodoras linnelli: Brazil (Amazonas drainage): MZUSP 29033 (8, 51-58.6 mm SL), Amazonas, Barcelos, rio Negro. MZUSP 29034 (3, 64.7-126.4 $\mathrm{mm} \mathrm{SL})$, Amazonas, rio Marauiá (00² $\left.24^{\prime} \mathrm{S} 65^{\circ} 12^{\prime} \mathrm{W}\right)$. MZUSP 31102 (1, $112.7 \mathrm{~mm} \mathrm{SL})$, Amazonas, rio Marauiá (00²4'S $\left.65^{\circ} 12^{\prime} \mathrm{W}\right)$. MZUSP 57321 (1, $\left.44.2 \mathrm{~mm} \mathrm{SL}\right)$, Amazonas, rio Negro (0303'58"S 60¹4'35"W). MZUSP 66485 (1, $135 \mathrm{~mm} \mathrm{SL),}$ 
Amazonas, rio Tiquié, below Cachoeira do Caruru $\left(00^{\circ} 16^{\prime} 27^{\prime} \mathrm{N}\right.$ 6954'56”W). MZUSP 82299 (9, 130-151 mm SL), Amazon basin, probably rio Negro, M. Goulding. MZUSP 92441 (2, 152-179 mm SL), Mato Grosso, rio Aripuanã (1009'54”S 59॰26'55”W). MZUSP 92506 (1, $117.9 \mathrm{~mm} \mathrm{SL})$, Amazonas, Igarapé Castanha, tributary of rio Tiquié $\left(00^{\circ} 12^{\prime} \mathrm{N} 69^{\circ} 35^{\prime} \mathrm{W}\right)$. MZUSP $93103(5,130.9-156 \mathrm{~mm}$ $\mathrm{SL})$, Amazonas, Igarapé Castanha, tributary of rio Tiquié $\left(00^{\circ} 05^{\prime} \mathrm{N}\right.$ 69³9'W). Leptodoras myersi: Brazil (Amazonas drainage): MZUSP 55839 (2, 84.5-98.4 mm SL), Amazonas, rio Solimões (03¹1'17'S 6448'47'W). MZUSP 56671 (1, $67.5 \mathrm{~mm} \mathrm{SL),} \mathrm{Amazonas,} \mathrm{rio}$ Amazonas. MZUSP 56672 (1, $89.8 \mathrm{~mm} \mathrm{SL})$, Amazonas, rio Amazonas. MZUSP 56676 (1, 118.3 mm SL), Amazonas, rio Solimões (02²7’21'’S 66³7’29”W). Leptodoras praelongus: Brazil (Amazonas drainage): MCP 24646 (1, $52.7 \mathrm{~mm} \mathrm{SL})$, rio Negro, below Carvoeiro. MZUSP 31694 (1, $211 \mathrm{~mm} \mathrm{SL),} \mathrm{rio} \mathrm{Xingu}$ (030'ㅇ 51 $\left.{ }^{\circ} 42^{\prime} \mathrm{W}\right)$, Pará, Belo Monte. MZUSP 32538 (3, 154-

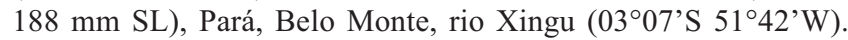
MZUSP $55841(6,58.4-75.2 \mathrm{~mm}$ SL), Amazonas, rio Negro (0141'13"S 6127'14"W). MZUSP 55844 (1, $66 \mathrm{~mm} \mathrm{SL})$, Amazonas, rio Negro $\left(01^{\circ} 23^{\prime} 01\right.$ '” $\left.61^{\circ} 55^{\prime} 08^{\prime \prime} \mathrm{W}\right)$. MZUSP 55846 (1, $72.7 \mathrm{~mm} \mathrm{SL})$, Amazonas, rio Negro. MZUSP 56041 (1, 56.6 $\mathrm{mm}$ SL), Roraima, rio Branco (01 ${ }^{\circ} 17 ’ 21^{\prime \prime} \mathrm{S} 61^{\circ} 50$ '50”W). MZUSP 56241 (2, 65.6-70 mm SL), Amazonas, rio Negro. MZUSP 56300 (1, $52.1 \mathrm{~mm} \mathrm{SL})$, Amazonas, rio Negro. MZUSP 56301 (2, 60.3-

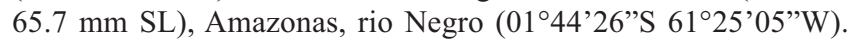
MZUSP 56663 (1, $55.7 \mathrm{~mm}$ SL), Amazonas, rio Jutaí. MZUSP 56668 (1, $67.7 \mathrm{~mm} \mathrm{SL})$, Amazonas, rio Branco. MZUSP 56670 (3, 52.2-57 mm SL), Amazonas, rio Jutaí. MZUSP 56673 (5, 63.9$91.2 \mathrm{~mm} \mathrm{SL})$, Roraima, rio Branco ( $01^{\circ} 18^{\prime} 18^{\prime}$ 'S 61 $51^{\circ} 40$ ”'W). MZUSP 56674 (15, $70 \mathrm{~mm} \mathrm{SL,} 1 \mathrm{cs}, 80 \mathrm{~mm} \mathrm{SL})$, Roraima, rio Branco (0118'49'S 61 ${ }^{\circ} 52$ '03'W). MZUSP 56675 (15, 61.9-96.5 $\mathrm{mm}$ SL), Amazonas, rio Negro (01 $\left.{ }^{\circ} 50^{\prime} 58^{\prime \prime S} 61^{\circ} 24^{\prime} 04^{\prime \prime} \mathrm{W}\right)$. MZUSP 57279 (1, $24.3 \mathrm{~mm} \mathrm{SL})$, Amazonas, rio Negro. MZUSP 57295 (3, 36.3-40.7 mm SL), Amazonas, rio Negro. MZUSP 57312 (5, 33.5$36.5 \mathrm{~mm}$ SL), Amazonas, rio Negro. MZUSP 57815 (3, 36.1-39.1 mm SL), Amazonas, rio Negro. MZUSP 58009 (15, 39.5-63.5 mm SL), Amazonas, rio Madeira. MZUSP 58080 (1, $72.8 \mathrm{~mm} \mathrm{SL})$, Amazonas, rio Negro. MZUSP 58082 (2, 27.4-40 mm SL), Amazonas, rio Negro. MZUSP 58206 (1: 94.5 mm SL), Pará, rio Amazonas. MZUSP 74182 (2, 46.2-49.8 mm SL), Amazonas. MZUSP 98711 (1, $64.7 \mathrm{~mm} \mathrm{SL})$, rio Negro $\left(01^{\circ} 18^{\prime} 12^{\prime \prime S}\right.$ 6157’41”W), Amazonas. MZUSP 53818 (2, 154.6-169 mm SL), rio Araguaia, lago Furo da Aldeia. MZUSP 74696 (2, 122.8-129.7 mm SL), Amazonas, Tefé, rio Tefé (0322'S 6443'W). MZUSP 57330 (1, $112.9 \mathrm{~mm}$ SL), Pará, Monte Dourado, rio Jari (0043'7’'S 52²9’43”W). MZUSP 29026 (1, 137.9 mm SL), Amazonas, rio Tefé, Jurupari. MZUSP 58084 (1, 63 mm SL), Pará, rio Amazonas. MZUSP 55845 (1, $57.1 \mathrm{~mm} \mathrm{SL})$, Amazonas, rio Negro (01²3'03'’S 61 $55^{\circ}$ '46”W). MZUSP 58132 (2, 64.6-77.2 mm SL), Amazonas, rio Negro. MZUSP 56665 (1, $63.9 \mathrm{~mm} \mathrm{SL})$, Amazonas, rio Negro. MZUSP 98710 (1, 45.6 mm SL), Amazonas, Caracaraí, rio Negro (0123'12'S 6153'49'W).

\section{Acknowledgments}

The manuscript benefited from comments and suggestions from Alberto Akama and Carl Ferraris. For loan and exchanges we thank Osvaldo Oyakawa (MZUSP), Margarete Lucena (MCP), Marcelo Britto (MNRJ), Lúcia Rapp Py-Daniel and Marcelo Rocha (INPA), and Nathan Lujan (AUM). For help preparing dry skeletons we thank Douglas M. de Souza (MZUSP). We thank Alberto Akama, Alexandre K. Oliveira, Aléssio Datovo, André Netto Ferreira, Carlos Figueiredo, Cristiano Moreira, Francisco Machado, Isabel Landim, José César Nolasco, Lício Moraes, Nathan Lujan and Osvaldo Oyakawa for help in the field. We are also grateful to All Catfish Species Inventory (NSF DEB-0315963) for funding the PIPE expedition to Serra do Cachimbo, Brazil, in October 2008 (http://silurus.acnatsci.org/ACSI/field/Pipe Expedition). The two senior authors were funded by FAPESP (06/53737-7 - JLOB and 06/04162-1 - LMS).

\section{Literature cited}

Arratia, G. 2003a. Catfish Head Skeleton-An Overview. Pp. 3-46. In: Arratia, G., B. G. Kapoor, M. Chardon \& R. Diogo. (Eds.) Catfishes. Engield, New Hampshire, U.S.A., Science Publishers, Inc., 812p.

Arratia, G. 2003b.The Siluriform Postcranial Skeleton - An Overview. Pp. 121-158. In: Arratia, G., B. G. Kapoor, M. Chardon \& R. Diogo. (Eds.) Catfishes. Engield, New Hampshire, U.S.A., Science Publishers, Inc., 812p.

Birindelli, J. L. O. 2006. Revisão e filogenia de Rhinodoras Bleeker, 1862 (Doradidae, Siluriformes). Unpublished Master dissertation, Universidade de São Paulo, São Paulo, Brazil, 274p.

Birindelli, J. L. O., M. H. Sabaj \& D. Taphorn. 2007. New species of Rhynchodoras from the Río Orinoco, Venezuela, with comments on the genus (Siluriformes: Doradidae). Copeia, 2007 (3): 672-684.

Chardon, M., E. Parmentier \& P. Vandewalle. 2003. Morphology, development and evolution of the Weberian Apparatus in Catfish. Pp. 71-120. In: Arratia, G., B. G. Kapoor, M. Chardon \& R. Diogo. (Eds.) Catfishes. Engield, New Hampshire, U.S.A., Science Publishers, Inc., 812p.

Ferraris, Jr., C. J. 2007. Checklist of catfishes, recent and fossil (Osteichthyes: Siluriformes), and catalogue of siluriform primary types. Zootaxa, 1418:1-628.

Higuchi, H. 1992. A phylogeny of the South American thorny catfishes (Osteichthyes; Siluriformes; Doradidae). Unpublished Ph.D. dissertation, Havard University, Cambridge. 372p.

Higuchi, H., J. L. O. Birindelli, L. M. Sousa \& H. A. Britski. 2007. Merodoras nheco, new genus and species from Rio Paraguay basin, Brazil (Siluriformes: Doradidae), and nomination of the new subfamily Astrodoradinae. Zootaxa, 1446: 31-42.

Higuchi, H., H. A. Britski \& J. C. Garavello. 1990. Kalyptodoras bahiensis, a new genus and species of thorny catfish from northeastern Brazil (Siluriformes: Doradidae). Ichthyological Explorations of Freshwaters, 1(3): 219-225.

Moyer, G. R., B. M. Burr \& C. Krajewski. 2004. Phylogenetic relationships of thorny catfishes (Siluriformes: Doradidae) inferred from molecular and morphological data. Zoological Journal of the Linnean Society, 140: 551-575.

Sabaj, M. H. 2002. Taxonomy of Doradidae (Actinopterygii: Siluriformes) with revision and phylogeny of genus Leptodoras. Unpublished Ph.D. dissertation, University of Illinois, 422p.

Sabaj, M. H. 2005. Taxonomic assessment of Leptodoras (Siluriformes: Doradidae) with descriptions of three new species. Neotropical Ichthyology, 3(4): 637-678.

Sabaj Pérez, M. H., O. A. Aguilera S. \& J. G. Lundberg. 2007. Fossil 
catfishes of the families Doradidae and Pimelodidae (Teleostei: Siluriformes) from the Miocene Urumaco Formation of Venezuela. Proceedings of the Academy of Natural Sciences of Philadelphia, 156: 157-194.

Sabaj Pérez, M. H. \& J. L. O. Birindelli. 2008. Taxonomic revision of extant Doras Lacepède, 1803 (Siluriformes: Doradidae) with descriptions of three new species. Proceedings of the Academy of Natural Sciences of Philadelphia, 157: 189-233.

Sabaj, M. H., D. C. Taphorn \& O. E. Castillo. 2008. Two new species of Thicklip thornycats, genus Rhinodoras (Teleostei: Siluriformes: Doradidae). Copeia, 2008 (1): 209-226.

Taylor, W. R. \& G. C. Van Dyke. 1985. Revised procedures for staining and clearing small fishes and other vertebrates for bone and cartilage study. Cybium, 9: 107-119.

Accepted September, 2008

Published September 30, 2008 